\title{
Thyroid nodules and differentiated thyroid cancer: update on the Brazilian consensus
}

\author{
Nódulo tireoidiano e câncer diferenciado de \\ tireoide: atualização do consenso brasileiro
}

Pedro Weslley Rosário', Laura S. Ward², Gisah A. Carvalho³, Hans Graf ${ }^{3}$, Rui M. B. Maciel' ${ }^{4}$, Léa Maria Z. Maciel $^{5}$, Ana Luiza Maia6, Mário Vaisman

'Serviço de Endocrinologia e Instituto de Ensino e Pesquisa, Santa Casa de Belo Horizonte, Belo Horizonte, MG, Brazil ${ }^{2}$ Laboratório de Genética Molecular do Câncer e Endocrinologia Departamento de Clínica Médica, Faculdade de Ciências Médicas,

Universidade Estadual de Campinas (FCM/Unicamp), Campinas, SP, Brazi

${ }^{3}$ Serviço de Endocrinologia e Metabologia, Universidade Federal do Paraná (SEMPR/ UFPR), Curitiba, PR, Brazil

${ }^{4}$ Disciplina de Endocrinologia, Departamento de Medicina, Escola Paulista de Medicina, Universidade Federal de São Paulo (EPM/ Unifesp), São Paulo, SP, Brazil

${ }^{5}$ Divisão de Endocrinologia, Departamento de Clínica Médica, Faculdade de Medicina de Ribeirão Preto, Universidade de São Paulo (FMRP-USP), Ribeirão Preto, SP, Brazil

${ }^{6}$ Setor de Tireoide, Serviço de Endocrinologia, Hospital de Clínicas de Porto Alegre, Universidade Federal do Rio Grande do Sul (HCUFRGS), Porto Alegre, RS, Brazil

${ }^{7}$ Serviço de Endocrinologia, Hospital Universitário Clementino Fraga Filho, Faculdade de Medicina, Universidade Federal do Rio de Janeiro (HUCFF/UFRJ), Rio de Janeiro, RJ, Brazil

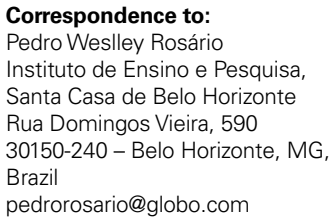

\begin{abstract}
Thyroid nodules are frequent findings, especially when sensitive imaging methods are used. Although thyroid cancer is relatively rare, its incidence is increasing, particularly in terms of small tumors, which have an uncertain clinical relevance. Most patients with differentiated thyroid cancer exhibit satisfactory clinical outcomes when treatment is appropriate, and their mortality rate is similar to that of the overall population. However, relapse occurs in a considerable fraction of these patients, and some patients stop responding to conventional treatment and eventually die from their disease. Therefore, the challenge is how to identify the individuals who require more aggressive disease management while sparing the majority of patients from unnecessary treatments and procedures. We have updated the Brazilian Consensus that was published in 2007, emphasizing the diagnostic and therapeutic advances that the participants, representing several Brazilian university centers, consider most relevant in clinical practice. The formulation of the present guidelines was based on the participants' experience and a review of the relevant literature. Arq Bras Endocrinol Metab. 2013;57(4):240-64
\end{abstract}

\section{Keywords}

Thyroid nodules; thyroid cancer; Brazilian consensus; update

\section{RESUMO}

Nódulos tireoidianos são muito frequentes, sobretudo quando se empregam métodos sensíveis de imagem. Embora o câncer seja proporcionalmente raro, sua incidência vem aumentando, especialmente de tumores pequenos, cuja evolução clínica é incerta. A maioria dos pacientes com carcinoma diferenciado de tireoide evolui bem quando adequadamente tratada, com índices de mortalidade similares à população geral. Por outro lado, um percentual não desprezível apresenta recidivas e alguns eventualmente não respondem às terapias convencionais, evoluindo para óbito. Assim, o desafio é distinguir os pacientes merecedores de condutas mais agressivas e, ao mesmo tempo e não menos importante, poupar a maioria de tratamentos e procedimentos desnecessários. Atualizamos o Consenso Brasileiro publicado em 2007, ressaltando os avanços diagnósticos e terapêuticos que os participantes, de diferentes Centros Universitários do Brasil, consideram mais relevantes para prática clínica. A elaboração dessas diretrizes foi baseada na experiência dos participantes e revisão da literatura pertinente. Arq Bras Endocrinol Metab. 2013;57(4):240-64

\section{Descritores}

Nódulo de tireoide; câncer de tireoide; consenso brasileiro; atualização 


\section{INTRODUCTION}

S everal thyroid diseases may present as nodules. $\checkmark$ According to population-based studies conducted with adults in iodine sufficient areas, approximately 4 to $7 \%$ of women and $1 \%$ of men exhibit palpable thyroid nodules $(1,2)$. However, the prevalence of nodules indicated by ultrasound exams (US) is substantially higher, reaching up to $68 \%$ of the population $(3,4)$; such high frequencies are usually found among older women (5). Although most thyroid nodules are benign, the possibility of a malignancy must be ruled out; $95 \%$ of malignant tumors are well-differentiated carcinomas $(6,7)$.

Although the current incidence of thyroid cancer is not higher than 24 cases per 100,000 people (7), the incidence has been increasing in recent years $(7)$ to become the fourth most common type of malignant tumor among Brazilian women (8). This increased incidence is mostly associated with a greater number of small papillary carcinomas (6).

The recommendations described here were prepared according to the model provided by Project Guidelines (Projeto Diretrizes) by the Brazilian Medical Association (Associação Médica Brasileira $\mathrm{AMB}$ ) and Federal Council of Medicine (Conselho Federal de Medicina - CFM) (9), which is a nationwide initiative already known to the Brazilian medical and academic communities. Consistently, the recommendation levels or the strength of evidence degrees employed by that model were used, as described in Table 1 (9).

Following the selection of participants with established academic activity and clinical experience related to the thyroid, the clinical questions that grounded the recommendations were elaborated upon. The corresponding literature was located in the MedLine-PubMed, EMBASE, and SciELO-LILACS databases.

Table 1. Recommendations according to the level of evidence (9)

\begin{tabular}{|c|c|}
\hline Recommendation & Strength of evidence \\
\hline A & $\begin{array}{l}\text { Experimental and observational studies with better } \\
\text { consistency }\end{array}$ \\
\hline B & $\begin{array}{l}\text { Experimental and observational studies with less } \\
\text { consistency }\end{array}$ \\
\hline C & Case reports (non-controlled studies) \\
\hline D & $\begin{array}{l}\text { Opinion lacking critical assessment, based on } \\
\text { consensus, physiological studies, or animal models }\end{array}$ \\
\hline
\end{tabular}

\section{APPROACH TO PATIENTS WITH THYROID NODULES}

\section{What clinical information must be collected?}

With regard to patients with thyroid nodules, a thorough clinical interview and physical examination must be performed. Although these methods are most often neither sensitive nor specific, some of the data they provide are indicative of a higher risk of malignancy $(5,10$ 14) (Table 2).

Table 2. Data from the clinical history and physical examination that suggest a greater risk of malignancy in thyroid nodules

Male gender; age $<20$ or $>70$ years old; history of exposure to ionizing radiation or neck radiotherapy in childhood or adolescence; previous diagnosis of thyroid cancer treated by means of partial thyroidectomy

Family (first degree) history of thyroid cancer, especially when affecting two or more relatives in the case of differentiated carcinoma

Hereditary syndromes such as multiple endocrine neoplasia type 2 (MEN II), Cowden syndrome, Pendred syndrome, Werner syndrome, Carney complex, and familial adenomatous polyposis

Fast-growing or large nodules with compressive symptoms ${ }^{\mathrm{a}}$

Hard nodules, adhered to deep tissues, with little mobility; associated with paralysis of the ipsilateral vocal cord; or cervical lymphadenopathy ${ }^{\text {a }}$

Nodules incidentally detected on FDG-PET (focal uptake) in cancer patients

${ }^{a}$ Confirmation of these data as being suspicious of malignancy requires comparison with the results of imaging exams.

As will be subsequently shown, nodules that are large or are considered suspicious upon a US exam must be subjected to fine needle aspiration (FNA) biopsy, regardless of the patient's clinical history. Conversely, nodules that are small and are not considered suspicious upon US require further investigation only in patients with high clinical risk of malignancy, in which case the personal and family history become significantly relevant.

\section{Recommendation 1}

Individuals with a personal or family history of thyroid cancer, a history of exposure to radiation in childhood or adolescence, or nodules incidentally discovered on fluorodeoxyglucose positron emission tomography (FDG-PET; focal uptake) are considered to be at high risk for thyroid malignancy (Recommendation B).

\section{What are the recommended laboratory tests?}

\section{Serum thyroid-stimulating hormone (TSH)}

As clinical assessment is not always indicative of thyroid dysfunction, TSH levels must be measured. 
Whenever hyperfunction is detected, even when it is subclinical, thyroid scintigraphy, preferably with radioactive iodine (RAI), is indicated to establish whether the nodule has high or low uptake. In approximately $10 \%$ of the patients with solitary nodules, TSH is suppressed and the nodule has high uptake. In such cases, FNA is unnecessary because this type of nodule is exceptionally malignant $(5,15)$.

When TSH levels are elevated, the levels of antithyroid peroxidase (anti-TPO) antibodies may be measured to confirm a diagnosis of autoimmune thyroiditis. When the US shows a well-defined nodule, the criteria to indicate an FNA are the same in patients with and without Hashimoto's thyroiditis (16). Although some studies have shown a direct correlation between serum TSH levels and risk of malignancy in thyroid nodules and even with initial staging $(17,18)$, the currently available data do not support the indication of any particular approach of patients with thyroid nodules and normal-to-high or high TSH levels.

\section{Serum calcitonin and thyroglobulin levels}

Several studies have assessed the utility of serum (basal and stimulated) calcitonin for early diagnosis of sporadic medullary thyroid carcinoma (MTC) in patients with thyroid nodules (19-22). However, the interpretation of calcitonin (basal and stimulated) results and the cost-benefit ratio are controversial and may be more interesting in patients who have small nodules and are over 40 years of age (21). The sensitivity and specificity of the serum thyroglobulin ( $\mathrm{Tg}$ ) levels are relatively low for the diagnosis of thyroid cancer (23).

\section{Recommendation 2}

Serum TSH levels must be measured at the initial assessment, primarily to eliminate the possibility of autonomous or hyperfunctioning nodules (Recommendation A).

\section{Recommendation 3}

Except for patients with clinical suspicion or family history of MTC or multiple endocrine neoplasia type 2 (MEN II), measurement of serum calcitonin is not necessary (Recommendation C).

\section{Recommendation 4}

Serum $\mathrm{Tg}$ levels are not recommended to distinguish between benign and malignant thyroid nodules (Recommendation B).

\section{What is the role of the imaging methods?}

\section{Neck ultrasound}

US is an excellent method for the detection of thyroid nodules, with a sensitivity of approximately $95 \%$ (24), which is higher than other sophisticated methods such as computed tomography (CT) and magnetic resonance imaging (MRI) and often results in modifications of decisions exclusively based on the findings upon palpation (25). US allows for the assessment of the nodule size, composition, and characteristics. In addition, US might detect suspicious lymph nodes in the neck and eventually the compression or invasion of thyroid adjacent structures (26).

US is also used in diagnostic (e.g., directed FNA) and therapeutic (e.g., cyst aspiration, ethanol injection, laser therapy) procedures and to monitor nodule growth.

Some US findings are associated with increased risk of malignancy. Such findings include hypoechogenicity (especially if there is marked hypoechogenicity); microcalcifications; irregular margins; predominantly or exclusively central vascularization detected by Doppler; larger anteroposterior diameter compared with the transverse diameter (27-31); and, more specifically, the detection of lymph nodes of the neck with suspicious characteristics. Nevertheless, US findings alone do not allow for absolute differentiation between benign and malignant lesions (24).

Assessment of the nodule elasticity (elastography) demonstrates greater rigidity in malignant tumors. Although elastography cannot replace conventional US, when performed together (elastography plus US), the sensitivity and specificity of the assessment improve (32). In addition, the instances in which elastography might be clinically decisive when combined with US must still be established as well as its limitations and potential means of minimizing these limitations (33).

\section{Recommendation 5}

Neck US must be performed in all patients with thyroid nodules (Recommendation A).

\section{Computed tomography, magnetic resonance imaging, and positron emission tomography}

Neither CT nor MRI can differentiate between benign and malignant lesions as well as US; therefore, these methods are seldom indicated for the assessment of thyroid nodules. However, these imaging modalities 
are useful in the assessment of substernal goiter and the compression or invasion of adjacent structures, such as the trachea (34). Although ${ }^{18} \mathrm{FDG}$-PET is useful in the differentiation between benign and malignant lesions (35), this technique is still not readily accessible and is quite expensive. In addition, this sophisticated technique does not allow for the dismissal of FNA and might be more useful for the cases with undetermined cyto$\operatorname{logy}(35)$.

\section{Recommendation 6}

CT, MRI, and FDG-PET are seldom necessary for the assessment of thyroid nodules (Recommendation B).

\section{Isotope scintigraphy}

Scintigraphy with radionuclides is important to determine whether nodules are hyperfunctioning. Hyperfunctioning nodules with or without extra-nodular suppression are exceptionally malignant $(5,15)$. Scintigraphy may be performed with ${ }^{131} \mathrm{I}$ or ${ }^{123} \mathrm{I}$ or ${ }^{99 \mathrm{~m}} \mathrm{Tc}$ pertechnetate. The iodine radioisotopes are absorbed and organified by the thyroid and are the preferred isotypes because 3 to $8 \%$ of nodules that are hyperfunctioning when mapped with ${ }^{99 \mathrm{~m}} \mathrm{Tc}$ scans are hypofunctioning with iodine (36). Scintigraphy is also indicated for nodules with cytology, which is suggestive of follicular tumor in patients with normal low or low TSH, if it was not performed earlier (37).

\section{Recommendation 7}

Thyroid scintigraphy is indicated when a functioning nodule is suspected (subnormal TSH) (Recommendation A) or cytology is suggestive of follicular tumor (Recommendation B).

\section{When is a fine needle aspiration biopsy indicated?}

FNA is the best available method to distinguish between benign and malignant lesions (5), even in the case of nodules smaller than $1 \mathrm{~cm} \mathrm{(3)}$ or larger than $4 \mathrm{~cm}$ (38). In addition, FNA is an easy and low-cost outpatient procedure that is virtually devoid of serious complications. Nevertheless, we emphasize the importance of having an experienced physician perform this procedure as well as the necessity of an experienced cytopathologist who can accurately analyze the biopsy material.

Thyroid nodules smaller than $1 \mathrm{~cm}$ represent microcarcinomas in a considerable percentage of cases (3).
Nevertheless, the high frequency of microcarcinomas found only in autopsies (39), their low rate of progression even when untreated $(40,41)$, and the fact that the probability of a cure is not affected when treatment is delayed until the tumor exhibits growth (40) minimize the concerns associated with the detection of microcarcinomas. Consistently, the investigation focuses on the diagnosis of carcinomas larger than $1 \mathrm{~cm}$.

\section{Recommendation 8}

When hyperfunctioning or purely cystic nodules have been ruled out, the indication for FNA is based on the patient's clinical history, nodule size, and US findings (Recommendation B). These indications are summarized in table 3 .

Table 3. Indications for FNA in patients with thyroid nodules (except for hyperfunctioning or purely cystic nodules)

\begin{tabular}{|c|c|}
\hline Nodule size & FNA indicated \\
\hline$<5 \mathrm{~mm}$ & Not indicated \\
\hline$\geq 5 \mathrm{~mm}$ & $\begin{array}{l}\text { Patients with high risk of malignancy } \\
\text { or suspicious nodule on US }\end{array}$ \\
\hline$\geq 10 \mathrm{~mm}$ & Solid hypoechoic nodule \\
\hline$\geq 15 \mathrm{~mm}$ & Solid iso- or hyperechoic nodule ${ }^{b}$ \\
\hline$\geq 20 \mathrm{~mm}$ & Complex or spongiform nodule ${ }^{b}$ \\
\hline $\begin{array}{l}\text { Nodule with apparent extrathyroidal } \\
\text { invasion }\end{array}$ & All \\
\hline Suspicious lymph node upon US & Lymph node FNA \\
\hline
\end{tabular}

\section{What approaches follow from cytology?}

The National Cancer Institute (NCI, USA) held a multidisciplinary conference, which established that the cytopathology results must reflect the cytopathologist's diagnostic impression in a succinct and clear manner without leaving room for interpretative misunderstandings. The classification system suggested for that purpose, known as Bethesda System (42), is described in table 4 . The approach of patients based on the cytology results is depicted below (Figure 1).

\section{Recommendation 9}

Surgery is recommended when cytology results indicate a suspicious malignancy (Bethesda category V) or confirmed malignancy (Bethesda category VI) (Recommendation A). 
Table 4. Bethesda system of thyroid cytopathology reports

\begin{tabular}{cl}
\hline Category & \\
\hline I & Non-diagnostic or unsatisfactory sample \\
III & Benign \\
IV & Atypia/follicular lesion of undetermined significance \\
V & Sollicular tumor or suspicious for follicular tumor \\
VI & Malignant \\
\hline
\end{tabular}

\section{Recommendation 10}

When the cytology results are indicative of a follicular tumor (Bethesda category IV), scintigraphy is useful for decision making. Removal of hyperfunctioning nodules is not mandatory; however, hypofunctioning nodules remain an indication for surgery (Recommendation B).

\section{Recommendation 11}

When cytology indicates follicular lesion or atypia with undetermined significance (Bethesda category III), it is recommended to repeat the FNA 3 to 6 months later. When the results persist, surgery is indicated for patients with high clinical or ultrasonographic suspicion of malignancy or nodules larger than $2 \mathrm{~cm}$. Patients with nodules $\leq 2 \mathrm{~cm}$ and low clinical and ultrasonographic suspicion of cancer should be monitored (Recommendation $\mathrm{C}$ ).

\section{Recommendation 12}

When the biopsy sample is unsatisfactory for cytological analysis (Bethesda category I), it is recommended to repeat the US-directed FNA 3 to 6 months later (Recommendation $\mathrm{B})$. When the results persist, surgery is indicated for patients with high clinical or ultrasonographic suspicion of malignancy or nodules larger than $2 \mathrm{~cm}$. Patients with nodules $\leq 2 \mathrm{~cm}$ and low clinical and ultrasonographic suspicion of cancer should be monitored (Recommendation C).

Some studies (43-45) have shown that when cytology is benign but the nodule exhibit a combination of US findings compatible with malignancy, repetition of the FNA can be useful, regardless of the nodule growth, as the rate of malignancy in such discordant cases is substantially higher than the traditional falsenegative rate of FNA, which varies from 1 to $3 \%$ (42).

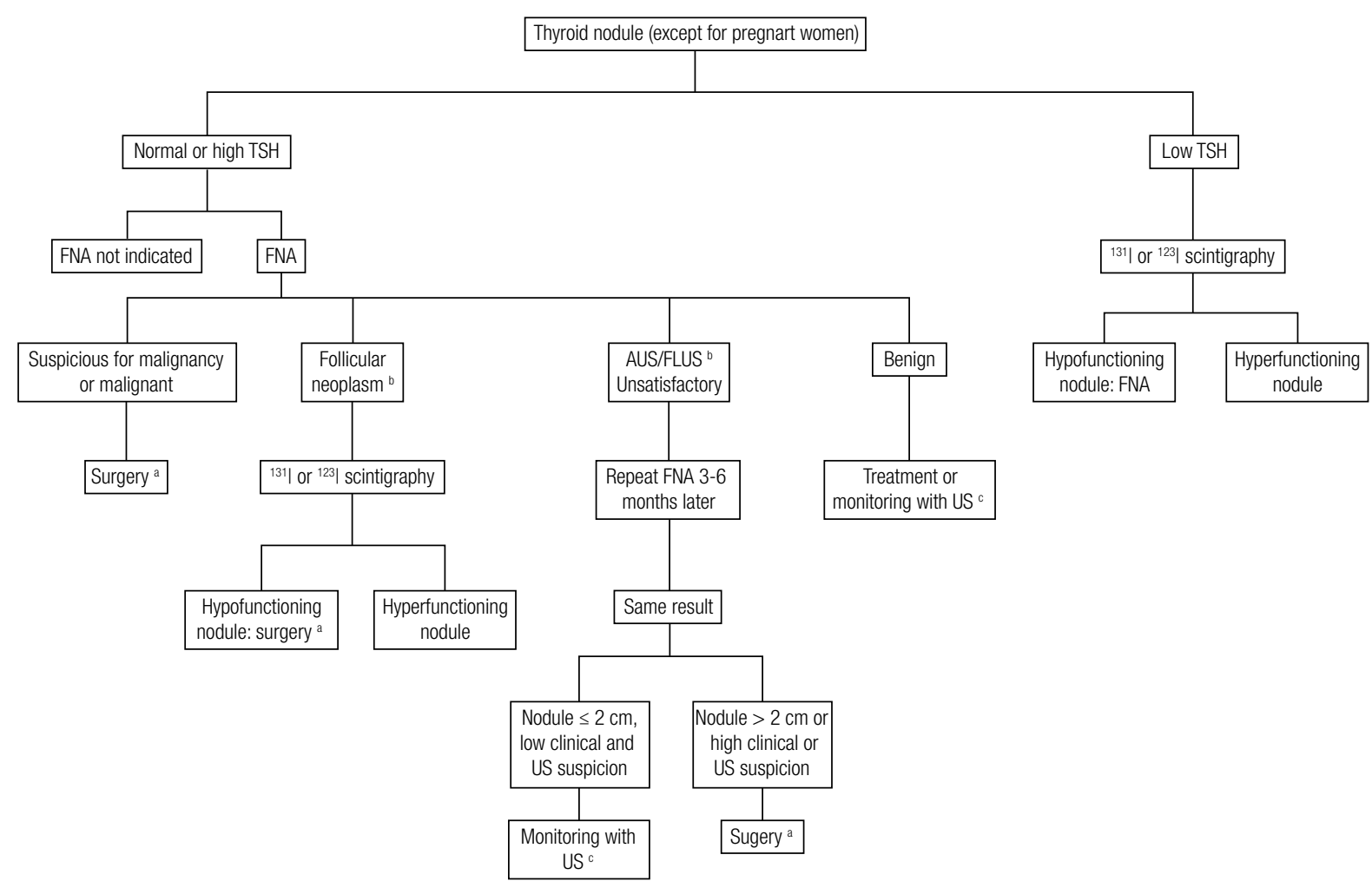

AUS, atypia of uncertain significance; FLUS, follicular lesion of uncertain significance.

a See the extent of surgery in R14, R15, R28, R30-32.

${ }^{\mathrm{b}}$ When available, molecular markers are useful.

c See R24-26.

Figure 1. Suggested approach in patients with thyroid nodules. 
${ }^{18}$ FDG-PET helps rule out malignancy in thyroid nodules with undetermined cytology (35); however, as it is expensive and not readily accessible, ${ }^{18} \mathrm{FDG}$-PET is not recommended as a routine procedure in this context.

\section{What is the utility of molecular markers?}

Several molecular markers have been assessed, especially with regard to thyroid nodules with undetermined cytology. Markers such as HBME, galectin, and CK19, among others, can be measured by any laboratory that performs routine immunohistochemical tests. Such markers are helpful in the identification of malignant tumors, particularly papillary carcinomas (46). Although their sensitivity reaches 0.85 to 0.93 , their specificity varies from 0.43 to 0.71 at most (47). Mutations in specific genes (such as BRAF V600E and $R A S$ ) or gene rearrangements (such as RET/PTC and PAX8-PPARy) can also contribute to the identification of malignancy (48). Unfortunately, a panel with these four markers (BRAF, RAS, and rearrangements RET/PTC and PAX8/PPARy) fails to identify $36 \%$ of malignant cases (sensitivity of $64 \%$ ) in clinical practice (49). Other markers, such as microRNAs, are being investigated (50). Recently, a novel test designed to rule out malignancy exhibited a high negative predictive value $(95 \%)$ in nodules with undetermined cyto$\log (51)$.

\section{Recommendation 13}

Molecular markers are helpful in defining the nature of thyroid nodules, especially those with undetermined cytology (Bethesda category III or IV) (Recommendation A). Consistently, the surgical recommendations above (especially $\mathbf{R} \mathbf{1 0}$ and $\mathbf{R} \mathbf{1}$ ) may be modified when molecular markers are used.

\section{What should the extent of the surgery be when malignancy is undetermined?}

\section{Recommendation 14}

A total thyroidectomy is recommended under the following conditions: (i) when a nodular disease is bilateral; (ii) when a nodular disease is associated with radiation; (iii) when the cytology is indicative of a suspicious malignancy; and (iv) when the cytology is undetermined and the nodule is $>4 \mathrm{~cm}$ or $\leq 4 \mathrm{~cm}$ but is associated with high clinical or US suspicion of cancer (Recommendation B).

\section{Recommendation 15}

Lobectomy is considered sufficient in unilateral and sporadic nodular disease when (i) the nodule $\leq 4 \mathrm{~cm}$, cytology is undetermined, and the clinical and ultrasonographic suspicion of malignancy is low or (ii) cytology is unsatisfactory (Recommendation B).

As the pre-test malignancy risk is modified when molecular markers or FDG-PET scans are used, the extent of surgery described above may be modified based on their results.

\section{What is the approach in children and adolescents?}

\section{Recommendation 16}

The recommendations described above also apply in the case of thyroid nodules in childhood and adolescence (Recommendation B).

In pregnant women, scintigraphy with isotopes is contraindicated. Surgery increases the risk of miscarriage in the first trimester and of premature birth in the third trimester; therefore, surgery is safest when performed in the second trimester (52). In addition, delay of the onset of treatment of differentiated carcinoma diagnosed in pregnancy does not appear to be associated with disease progression or interference with the probability of a cure (53). Based on those premises, the recommendations in nodules detected during pregnancy are as follows:

\section{Recommendation 17}

Pregnant women with large nodules, apparent invasion, or suspicious lymph nodes on US must be subjected to FNA (Recommendation A). In the remainder of cases, when TSH levels are spontaneously suppressed, follow up with US is recommended (Recommendation B). When TSH levels are normal or high, FNA is indicated as described in table 3; however, monitoring with US (without FNA) is also acceptable (Recommendation B).

\section{Recommendation 18}

When FNA is not performed in the initial assessment, it must be performed when the nodule exhibits significant growth in the course of pregnancy (Recommendation B).

\section{Recommendation 19}

In case of undetermined cytology, surgery may be indicated in the second trimester if there is significant nodule growth (Recommendation B). Surgery can also be 
performed in the second trimester when the cytology indicates a suspicious malignancy or malignancy and the tumor exhibits significant growth or the disease is in an advanced stage (Recommendation B). TSH levels must be kept low $(<0.5 \mathrm{mIU} / \mathrm{L})$ in patients with malignant cytology until surgery (Recommendation C).

\section{Recommendation 20}

Following delivery, patient management should be reassessed according to the usual recommendations (Recommendation A).

\section{When indicated, what are the non-surgical therapeutic options for benign nodular disease?}

Several studies have suggested that the use of levothyroxine (T4) with consequent reduction of TSH levels suppresses nodule growth (54-56). However, the adverse effects of hormone therapy on the cardiovascular system and bone metabolism $(57,58)$ limit its use.

Focal destruction by means of sclerotherapy with ethanol or laser photocoagulation can be considered in patients with benign solitary nodules $(59,60)$. When the main problem is thyroid hyperfunction caused by an autonomous nodule, long-term anti-thyroid drug treatment is an interesting option in elderly patients (60).

In several patients with multinodular goiter, iodine uptake is not homogeneous and is relatively low due to the presence of inactive nodules (i.e., "hypofunctioning" on scintigraphy) or suppression of the paranodular tissue. As such areas concentrate ${ }^{131}$ I very weakly, the efficacy of this treatment is compromised. The use of low doses of recombinant TSH significantly increases ${ }^{131} \mathrm{I}$ uptake in such patients and allows even low activities to efficiently reduce the goiter size by 30 to $50 \%$ in one year (60-62).

\section{Recommendation 21}

Suppressive treatment with T4 is not recommended for thyroid benign nodular disease (Recommendation B).

\section{Recommendation 22}

Sclerotherapy with alcohol can be considered for cystic or predominantly cystic nodules (Recommendation B).

\section{Recommendation 23}

Treatment of a nontoxic multinodular goiter with ${ }^{131} \mathrm{I}$ can be optimized through previous administration of low doses of recombinant TSH (Recommendation B).
How should the patients not subjected to surgery be monitored?

Although the malignancy risk of nodules without indication for FNA (63) or surgery is low [benign cytology $(5,42)$, small nodules with unsatisfactory cytology $(64,65)$ or undetermined follicular lesions/atypia, and non-suspicious clinical history and US], monitoring with US is recommended to detect eventual nodule growth, although its low specificity for a malignancy diagnosis is an acknowledged fact $(44,66)$. The interval between the US tests varies from 6 to 24 months and is defined depending on the number of previous assessments and changes in the nodule size in relation to previous US(s).

\section{Recommendation 24}

When an FNA is not performed in the initial assessment, it must be performed when the nodules meet the criteria listed in Table 3 (Recommendation B).

\section{Recommendation 25}

In cases of benign cytology, FNA must be repeated when the nodules exhibit significant growth $(>50 \%$ compared with the initial volume; Recommendation C).

\section{Recommendation 26}

Surgery must be considered for nodules that progress over time and whose initial cytology was undetermined or unsatisfactory (Recommendation B).

\section{MANAGEMENT OF DIFFERENTIATED THYROID CARCINOMA}

In Brazil and worldwide, sensitive imaging methods such as US are becoming increasingly accessible to an aging population, thus increasing the number of individuals diagnosed with small nodules that, even when confirmed as malignant, exhibit uncertain progression. The high frequency of carcinomas that are only found during autopsies (39) and prospective studies conducted with Japanese patients with microcarcinomas not subjected to surgery $(40,41)$ suggest that a large number of these tumors never exhibit clinical progression, which appears to account for the low mortality rate of differentiated thyroid carcinomas (DTCs) in spite of its increased incidence $(6,7)$. 
Most patients with DTC exhibit good outcomes when they are appropriately treated. However, relapse occurs in a significant percentage of cases, and some of these cases stop responding to conventional treatment and eventually die from their disease. The challenge, therefore, is to identify the individuals who require more aggressive management, while at the same time, and equally importantly, sparing the majority of patients from unnecessary treatments and procedures. Therefore, for the purpose of therapeutic planning and the definition of the best follow-up approach for patients with DTC, assessment of the risk of disease recurrence and progression is crucial.

\section{When must initial surgery be performed?}

Thyroidectomy is indicated together with a DTC diagnosis. Nevertheless, patients with a low life expectancy due to an associated severe disease might be spared thyroidectomy and given palliative treatment in case of advanced or progressive disease. Similarly, when surgery represents a risk due to patient condition, but the patient is expected to improve, thyroidectomy might be delayed for some months, provided the tumor is not progressing or growing (67). The same applies to women diagnosed at the beginning of pregnancy, who should also be subjected to monitoring with US. Surgery may be indicated in the second trimester if the tumor is growing (see Recommendation 19) or after labor if the tumor is stable (53). In the absence of contraindications, TSH levels must be suppressed $(<0.5 \mathrm{mIU} / \mathrm{L})$ in patients who will not undergo surgery or must wait some months before the surgery is performed.

Except for exceptional circumstances, any delay between DTC diagnosis and thyroidectomy is unjustified.

\section{What preoperative assessment is recommended?}

Preoperative US must be performed to identify the tumor multicentrality, which is supportive of the choice of total thyroidectomy as initial treatment, as well as to look for non-palpable lymph node metastases $(26,68)$ because their presence requires modified neck dissection. Although it is not indicated for this purpose, US results may also suggest tracheal and/or esophageal invasion by the tumor (26). Any suspicious lymph nodes must be assessed by FNA.

CT, MRI, esophagoscopy, or laryngotracheoscopy are not routinely recommended and are only indicated in case of clinical or ultrasonographic suspicion of invasion of adjacent structures $(69,70)$. The use of iodinated contrast should be avoided; however, when iodinated contrast is necessary to better assess the extent of disease, the therapy with ${ }^{131} \mathrm{I}$, when indicated, must be deferred for at least one month (71).

As permanent recurrent laryngeal nerve injury is uncommon when a thyroidectomy is performed by experienced surgeons, and seldom occurs asymptomatically before surgery, we do not recommend a routine performance of preoperative video-laparoscopy. The same applies to the measurement of the serum calcium levels with regard to hypoparathyroidism.

\section{Recommendation 27}

Preoperative neck US is recommended, even in asymptomatic patients without palpable lymph nodes, to assess the tumor multicentrality, the presence of lymph node metastases, and the extrathyroidal invasion (Recommendation B). No other study is routinely recommended (Recommendation B).

\section{What must the extent of the thyroidectomy be?}

Total thyroidectomy is the most recommended surgical procedure in patients with DTC. Lobectomy may be indicated in patients with classic, unifocal, sporadic papillary carcinoma $\leq 1 \mathrm{~cm}$ and without apparent lymphadenopathy or extrathyroidal invasion $(67,72-75)$.

In patients initially subjected to partial thyroidectomy, surgical complementation may be avoided in cases of papillary carcinoma presenting with the characteristics described above as well as in cases of minimally invasive follicular carcinoma and the capsulated follicular variant of papillary carcinoma (without vascular invasion) measuring up to $2 \mathrm{~cm}$.

\section{Recommendation 28}

Total thyroidectomy is the surgical procedure of choice in patients with a preoperative diagnosis of papillary carcinoma (Recommendation A).

\section{Recommendation 29}

The indication for surgical complementation in patients initially subjected to partial thyroidectomy must take into account the anatomical-pathological data in particular and the individual risk posed by the novel intervention (Recommendation A). 


\section{What is the surgical management of lymph nodes?}

Lymph node metastases are frequent findings by the time the diagnosis of papillary cancer is established (76). As neck palpation does not produce abnormal findings in most cases (77), a preoperative US and careful perioperative assessment by the surgeon are needed. Whenever metastases are suspected based on US or during surgery, the patient should be subjected to a total thyroidectomy and therapeutic lymph node dissection, even in the case of tumors $\leq 1 \mathrm{~cm}$, because full tumor resection improves prognosis (78).

Even when preoperative US and perioperative assessment are negative, many patients with papillary carcinoma exhibit lymph node micrometastases in the central compartment (79). Nevertheless, there are no consistent data showing that elective dissection of those lymph nodes reduces the risk of relapse. Adjuvant therapy with ${ }^{131} \mathrm{I}$ and TSH suppression may help control the progression of eventual non-resected micrometastases (80). However, such progression likely does not occur naturally in most cases $(81)$.

Although some studies have reported low morbidity associated with central compartment lymph node elective dissection $(79,82)$, other authors found a higher risk of transient and permanent hypoparathyroidism (83), even when the procedure is performed by experienced surgeons.

The lymph nodes in the lateral compartments (II to IV) and the posterior triangle may also be affected by papillary thyroid cancer metastases (76). However, removal of those lymph nodes appears to exert significant impact only on patients with clinically or US-detected metastases (68).

\section{Recommendation 30}

When affection of the central compartment lymph nodes is suspected, therapeutic dissection of this compartment is indicated (Recommendation A). When the presence of metastasis is confirmed in the pre- or perioperative period, dissection must include the lymph nodes in the ipsilateral compartment (Recommendation B).

\section{Recommendation 31}

When affection of the lymph nodes in the lateral compartments is suspected, therapeutic dissection of these compartments is indicated (Recommendation A). When the presence of metastases is confirmed in the pre- or perioperative period, dissection must include the central compartment lymph nodes (Recommendation B).

\section{Recommendation 32}

In patients without suspected metastases on preoperative US and the surgeon's perioperative assessment, elective dissection of the central compartment lymph nodes may be considered when the tumors are $>4 \mathrm{~cm}$ or there is apparent extrathyroidal invasion (Recommendation $\mathrm{C}$ ).

Although the $B R A F$ gene mutation is associated with greater initial aggressiveness of papillary carcinoma, including higher frequency of lymph node metastases, the available data are not sufficient to rule out or indicate elective dissection of the central compartment lymph nodes on the grounds of the absence or presence of this mutation, respectively $(84,85)$.

\section{How must staging be performed after surgery?}

The aims of postoperative staging are as follows: 1) to estimate the mortality risk; 2 ) to establish the risk of relapse; 3 ) to assess the quality of surgery; 4 ) to define the initial individualized treatment; and 5) to make the terms uniform and facilitate the communication among the multidisciplinary staff that participates in patient treatment and follow up.

The staging system formulated by the American Joint Committee on Cancer/International Union against Cancer (AJCC/UICC) based on the tumor size, extrathyroidal invasion, lymph node and distant metastases (TNM), and age is recommended for all tumor types including thyroid tumors as an attempt to standardize the description of tumor extent. As that system does not consider other factors known to influence the progression and prognosis of DTC patients, its ability to predict the persistence and relapse of these tumors is limited, whereas it is more useful in the estimation of the mortality rate associated with the disease. In any case, the tumor size, presence and extent of extrathyroidal invasion and lymph node and distant metastases are relevant parameters in the choice of the initial treatment.

Some histological variants such as tall and columnar cells, extensively invasive follicular carcinoma, and poorly differentiated carcinoma exhibit more aggressive behavior $(72,78)$. Other signs of a poor prognosis include considerable nuclear atypia, tumor necrosis, and vascular invasion, all of which suggest lower grades of tumor differentiation (86).

The impact of lymph node compromise on the prognosis is controversial. According to prevailing opinions, lymph node metastases that are macroscopic, present in large numbers or characterized by extracapsular exten- 
sion increase the risk of relapse and mortality in patients older than 45 years old $(87,88)$.

Therefore, we describe four categories of risk of persistent or recurrent disease in table 5 .

We excluded children and adolescents from that stratification, as the classification of risk should be particularized in those cases because, despite the high frequency of cases of disease not restricted to the thyroid, their long-term prognosis is excellent $(67,72)$.

\section{Recommendation 33}

The initial staging of patients must be performed according to the TNM system. However, the stratification of risk must also consider other anatomical-pathological data (histological subtype, vascular invasion, free or affected margins) as well as the postoperative assessment to achieve better estimates of the risk of recurrence (Recommendation B).

\section{How are the tissues remaining after surgery quantified?}

Even when thyroidectomy is reported to be total, quantification of the remaining thyroid tissue is recommended, especially when surgery is performed by a surgeon with little or unknown experience. For that purpose, neck US is superior to scintigraphy and also provides information on the persistence of lymph node metastases $(89,90)$. For this purpose, a 3-month interval is required between surgery and ultrasonographic assessment (90). The analysis of vascularization using Doppler can be helpful in the differential diagnosis of

Table 5. Stratification of the risk of recurrence



LN: Iymph nodes; ECE: LN: extracapsular extent; WBS: whole body scan.

${ }^{a}$ Detected on clinical or radiological assessment or post therapy WBS; ${ }^{b}$ Based on the surgeon's description and postoperative assessment; ${ }^{\circ} \mathrm{cNO}$ : without metastases on pre- US and perioperative assessment, with (pNO) or without (pNx) elective dissection; ${ }^{\mathrm{d}}$ Only when ${ }^{131} \mathrm{I}$ ablation is indicated. 
lesions in the thyroid bed and in determining whether the lymph nodes are benign or metastatic.

\section{Recommendation 34}

Measurement of thyroid remnants and postoperative assessment of the neck must be preferentially performed using a Doppler US (Recommendation B).

\section{Recommendation 35}

Surgical reinterventions should be considered when the US shows large thyroid remnants or lymph node metastases (Recommendation B).

\section{When is ${ }^{131}$ I ablation/therapy indicated after total thyroidectomy?}

Treatment with ${ }^{131} \mathrm{I}$ is indicated for patients with incomplete tumor resection or apparent metastases after thyroidectomy and who are not candidates for surgical reintervention. In patients with apparently complete tumor resection but high or intermediate risk of persistent disease $(87,91)$, adjuvant ${ }^{131}$ I therapy impacts prognosis (92) and is thus recommended.

${ }^{131}$ I ablation is not indicated for very low-risk patients $(67,72,73,75,93-95)$.

In the remainder of patients, i.e., those with a low risk of persistent/recurrent disease, ablation is controversial $(67,96)$. In such cases, administration of ${ }^{131}$ I may confer additional benefits such as improvement of the serum $\mathrm{Tg}$ specificity and the early detection of metastasis on a whole body scan (WBS). Nevertheless, in patients with stimulated Tg levels $\leq 1 \mathrm{ng} / \mathrm{ml}$ and no abnormalities on an US a few months after thyroidectomy, the specificity of that marker is not affected by the remaining tissue; it is known that a WBS after ${ }^{131} \mathrm{I}$ administration does not detect metastases $(97,98)$; and the risk of relapse is low, even when ${ }^{131} \mathrm{I}$ is not administered $(90,99,100)$. For those reasons, this criterion suggests to dismiss ablation in the low-risk group (90,97-100).

Indication for ${ }^{131} \mathrm{I}$ must also consider the cost of treatment as well as its potential adverse effects such as transient alterations of the gonadal function (101103), acute sialadenitis (103), early menopause (104), and persistent xerostomia and xerophthalmia (105) in addition to a higher risk of second cancers (106).

\section{Recommendation 36}

${ }^{131} \mathrm{I}$ is indicated for patients subjected to total thyroidectomy and with known tumor persistence or high or intermediate risk of relapse (Recommendation B). With regard to low-risk patients, ablation should be dismissed when stimulated $\mathrm{Tg}$ levels are $\leq 1 \mathrm{ng} / \mathrm{ml}$ after surgery (Recommendation B). Ablation is not indicated in cases with a very low risk of relapse (Recommendation B).

\section{How should TSH stimulation be performed before ${ }^{131}$ I ablation/therapy?}

Human recombinant TSH is the pre-treatment procedure indicated for patients with conditions potentially aggravated by hypothyroidism [such as heart, lung, or atherosclerotic disease, kidney failure, severe depression, old age, and weakening diseases (107)] or with an inability to raise endogenous TSH to satisfactory levels (as in hypopituitarism). Even when none such condition is present, recombinant TSH is preferable when it is available in patients with complete tumor resection and no apparent metastasis after thyroidectomy because it is known to be efficacious in such cases (108-112). Furthermore, recombinant TSH exhibits advantages over discontinuation of T4: the quality of life of the patients is not affected; it eliminates the symptoms and eventual risk of hypothyroidism; and it is associated with shorter leaves of absence, less extrathyroidal radiation, and shorter exposure to high TSH levels $(103,108,109,111,113)$. In the remainder of patients (incomplete tumor resection or persistent metastases), discontinuation of T4 over 3 or 4 weeks is still the most proper indication in the absence of clinical contraindications. The latter recommendation also applies to children and adolescents because although the use of recombinant TSH is safe and apparently efficacious in them (114), further studies are required.

To perform ${ }^{131} \mathrm{I}$ ablation or therapy, one ampoule of recombinant TSH $(0.9 \mathrm{mg})$ is administered intramuscularly on two consecutive days followed by ${ }^{131} \mathrm{I}$ administration 24 hours after the second dose.

\section{Recommendation 37}

In the presence of clinical conditions potentially aggravated by hypothyroidism, recombinant TSH is the recommended pre-treatment (Recommendation A). In the absence of such conditions, the discontinuation of $\mathrm{T} 4$ is recommended in patients with known tumor persistence, as well as in both children and adolescents (Recommendation C). In the remainder of patients, recombinant TSH is recommended whenever it is available (Recommendation A). 


\section{What ${ }^{131}$ I activity should be administered?}

In patients with low risk of persistent or recurrent disease and in whom a total thyroidectomy was properly performed, an activity of $30 \mathrm{mCi}$ of ${ }^{131} \mathrm{I}$ is efficacious to achieve remnant ablation $(108,109,115-118)$ and exhibits low medium- and long-term relapse rates $(67,93,117,119)$. In this regard, two major randomized trials with 438 (108) and 756 (109) patients stand out. Both studies showed clearly that the efficacy of 30 $\mathrm{mCi}$ for the purpose of ablation was the same compared to $100 \mathrm{mCi}$ independent of the pre-treatment, i.e., discontinuation of T4 or recombinant TSH $(108,109)$. When the size of the thyroid remnant is uncertain, the parameters to indicate an activity of $30 \mathrm{mCi}$ are the volume measured on US $(\leq 2 \mathrm{~g})$, thyroid bed uptake $[\leq 2 \%(108,109,115)]$, or postoperative Tg levels $(97)$.

Activities of $200 \mathrm{mCi}$ or greater require caution when dosimetry is not available, particularly in the case of elderly or patients with diffuse lung metastases, because the maximum tolerated activity is commonly exceeded in such cases (120).

\section{Recommendation 38}

In low-risk patients, an activity of $30 \mathrm{mCi}$ is preferable, whereas a $100-\mathrm{mCi}$ activity is reserved for cases with known large tissue remnants (Recommendation A).

\section{Recommendation 39}

In patients without apparent disease, but intermediate or high risk, activity of $100 \mathrm{mCi}$ is recommended (Recommendation B).

\section{Recommendation 40}

In patients with local-regional tumor persistence, who are not candidates for surgical reintervention, activities of 100 or $150 \mathrm{mCi}$ are recommended (Recommendation $\mathrm{B})$.

\section{Recommendation 41}

An activity of $200 \mathrm{mCi}$ should only be considered for adults with known distant metastases (Recommendation $\mathrm{B})$.

\section{What other recommendations are important in ${ }^{131}$ I ablation/therapy?}

A low-iodine diet, usually $\leq 50 \mu \mathrm{g} /$ day for 7 to 14 days before the administration of ${ }^{131} \mathrm{I}$, appears to increase the uptake and radiation dose in the lesions (121). Nevertheless, the influence of a low-iodine diet on the success rate of ablation/therapy has not yet been demonstrated in a convincing manner (121). The corresponding studies are few, and none included a long-term assessment of the relapse and mortality rates (121). In addition to diet, other sources of iodine should be investigated (e.g., medications, syrups, dietary supplements, topic solutions, cosmetics). In addition, iodinated contrast agents are an important source of contamination, whose complete elimination requires at least one month (71).

Administration of furosemide and/or lithium before ${ }^{131}$ I may increase its uptake and the success rate of ablation performed with low ${ }^{131}$ I activity $(116,118)$; however, the available evidence does not suffice to recommend it as routine.

\section{Recommendation 42}

Despite its controversial benefit, a low-iodine diet must be prescribed due to its potentially positive effect and low cost (Recommendation B).

\section{Recommendation 43}

Women of reproductive age should be subjected to clinical and laboratory assessment (measurement of human chorionic gonadotropin; $\beta$-hCG) to rule out a pregnancy before administration of ${ }^{131} \mathrm{I}$. Pregnancy and breastfeeding are absolute contraindications to the use of RAI (Recommendation A). Women are advised to avoid conception for 6 to 12 months after RAI, and men are similarly advised for 3 months (Recommendation B).

\section{What tests must be performed before and immediately after ${ }^{131}$ I ablation/therapy?}

When TSH levels are $>30 \mathrm{mIU} / \mathrm{l}, \mathrm{Tg}$ levels after total thyroidectomy and immediately before ablation bear a direct correlation with the presence of persistent metastasis and WBS after treatment with RAI $(67,97,122)$, are predictive of the success of the ablation $(97,123)$, and behave as an important long-term prognostic factor $(122,124,125)$. In addition, in the patients with elevated $\mathrm{Tg}$ levels after initial treatment, comparison with the Tg levels obtained during the ablation is predictive of the clinical outcome (124,125).

WBS before RAI treatment exhibits a lower sensitivity for metastases compared to WBS after RAI treatment (126) and may also be associated with a risk of 
stunning, delayed treatment, and higher costs. Conversely, the post-treatment WBS exhibits higher sensitivity and is able to identify unsuspected metastases (67 ,87,91,97,98,109,111,122,126). Physiological uptake, or false-positive WBS results after treatment with RAI must be suspected when $\mathrm{Tg}$ is undetectable or low at the time of ablation [in the absence of anti-Tg antibodies $(\mathrm{TgAb})]$, when there is a lack of radiological correspondence to uptake, or when uptake occurs in sites unusual for metastases, particularly when isolated (127).

\section{Recommendation 44}

Measurement of serum $\mathrm{Tg}$ and $\mathrm{TgAb}$ must be performed immediately before ${ }^{131} \mathrm{I}$ administration (Recommendation B).

\section{Recommendation 45}

In patients with known anatomical-pathological and surgical data, WBS prior to treatment with RAI is not recommended (Recommendation B).

\section{Recommendation 46}

WBS must be performed 5 to 7 days after ${ }^{131} \mathrm{I}$ administration in any patient subjected to this therapy (Recommendation B). When the results of WBS after treatment with RAI are suggestive of metastasis, it is recommended to complement the assessment with an additional method to image the area corresponding to ectopic uptake (Recommendation B).

\section{What is the approach in patients already} subjected to thyroidectomy but with insufficient anatomopathological data for risk stratification?

In this circumstance, the assessment of the thyroid remnants and the determination of the presence of metastases are important. Initial assessment comprises clinical examination, serum $\mathrm{Tg}$ [T4] (i.e., without $\mathrm{TSH}$ stimulation) and TgAb levels, neck US, and simple chest $\mathrm{x}$-rays. Surgical reintervention must be considered when large thyroid remnants (128) or lymph node metastases are found. When neither US nor $\mathrm{x}$-rays show abnormalities, but $\mathrm{Tg}$ [T4] levels are higher than $1 \mathrm{ng} /$ $\mathrm{ml}$, it is recommended to administer 30 or $100 \mathrm{mCi}$ of ${ }^{131} \mathrm{I}$ based on $\mathrm{Tg}$ [T4] levels. When the initial assessment rules out persistent disease, stimulated $\mathrm{Tg}$ must be performed (following discontinuation of T4 or use of recombinant TSH) together with a diagnostic WBS.
An activity of $100 \mathrm{mCi}$ of ${ }^{131} \mathrm{I}$ is recommended when stimulated Tg levels are greater than $10 \mathrm{ng} / \mathrm{ml}$ under hypothyroidism or $5 \mathrm{ng} / \mathrm{ml}$ after use of recombinant TSH and a negative WBS. An activity of 100 to 200 $\mathrm{mCi}$ is recommended when WBS shows ectopic uptake, depending on the extent of the metastases.

\section{Recommendation 47}

In patients undergoing thyroidectomy, but whose anatomopathological data are not sufficient to establish appropriate risk stratification, a more thorough postoperative assessment is needed to determine the need for surgical reintervention and ${ }^{131} \mathrm{I}$ ablation or therapy (Recommendation A).

\section{When must external radiotherapy be included in the initial treatment?}

\section{Recommendation 48}

External radiotherapy must be considered for patients with incomplete tumor resection, who are not candidates for surgical reintervention, and when the tumor remnants exhibit low ${ }^{131}$ I uptake (Recommendation B).

\section{When must T4 replacement be initiated?}

In very low-risk individuals without indication for ${ }^{131} \mathrm{I}$ administration, T4 replacement must be initiated immediately after surgery. When recombinant TSH is used, there is no justification to delay T4 replacement. Similarly, in the case of low-risk patients in whom the decision to perform ${ }^{131} \mathrm{I}$ ablation depends on the Tg level approximately 12 weeks after surgery, hormone replacement must be initiated early. Finally, when the clinical, histological, and radiological data indicate the need for ${ }^{131} \mathrm{I}$ ablation/therapy, and the ${ }^{131} \mathrm{I}$ ablation/therapy will be performed within four weeks, T4 replacement may be delayed following thyroidectomy. However, when ${ }^{131} \mathrm{I}$ ablation/therapy is scheduled for a later period, T4 replacement must be initiated after surgery to avoid long-lasting hypothyroidism, and then discontinued.

When ${ }^{131} \mathrm{I}$ ablation/therapy is preceded by discontinuation of T4, hormone replacement must be restarted early, i.e., 48 hours after the administration of RAI, and at the full dose to promote rapid TSH reduction (113).

\section{Recommendation 49}

T4 therapy must be initiated as early as possible (Recommendation B). 
What is the indicated TSH level following initial treatment?

In patients with well-differentiated tumors, TSH suppression is an important adjuvant therapy. In individuals with known metastasis, TSH suppression has an inhibitory action on tumor growth and disease progression (67). In patients without apparent disease but with elevated $\mathrm{Tg}$ levels, low TSH levels contribute to the long-term negation of this marker (129). In addition, in cases without apparent disease but high risk of relapse, TSH suppression is associated with improved outcomes $(130,131)$. Even in low-risk patients under full remission, TSH levels persistently over $2 \mathrm{mIU} / \mathrm{ml}$ are associated with worse long-term progression (132).

Subclinical thyrotoxicosis is associated with bone mass compromise, especially among postmenopausal women $(57,58,133)$, and morphological and functional heart disorders $(57,58)$, which have more clinical repercussions among older adults. To minimize the adverse effects of suppressive therapy with T4, some steps are important. First, clinicians should pay attention to the fact that the TSH target must be individualized and subjected to constant reassessment (134), taking the presence of metastasis, Tg levels, and risk of relapse into account (Figure 2). Second, truly undetectable TSH is not necessary, and high serum T4 and especially T3 levels,

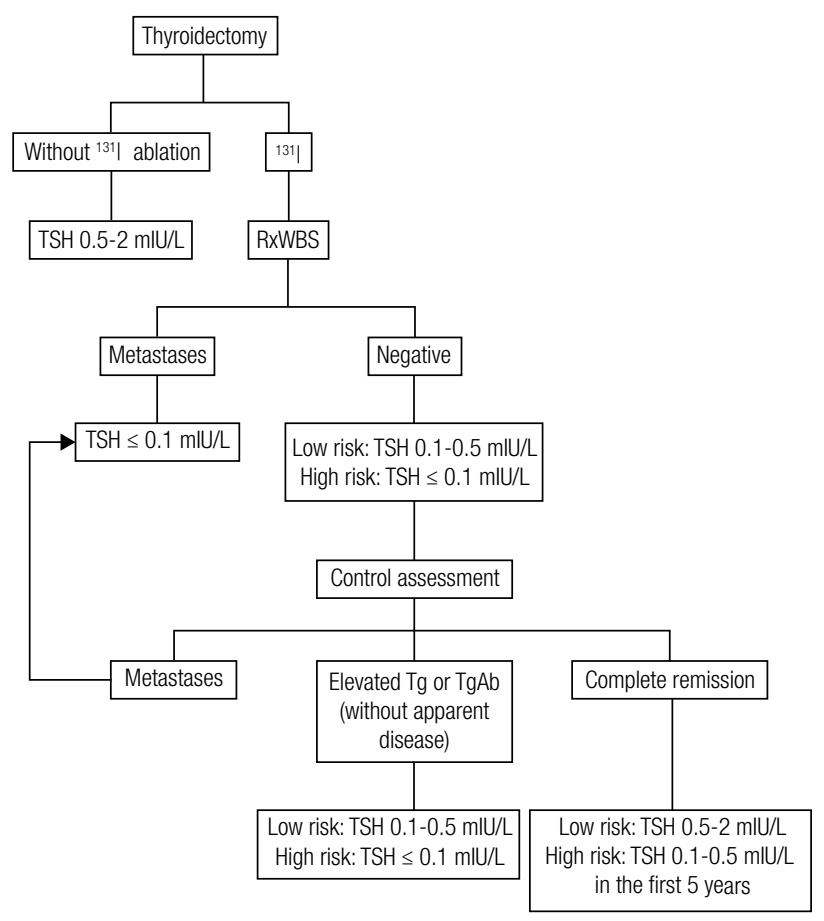

Figure 2. Recommended TSH levels after initial treatment in patients with differentiated thyroid cancer. must be avoided. Third, in addition to appropriate calcium and vitamin $\mathrm{D}$ intake (in all), periodic cardiovascular assessment (all) and bone densitometry (postmenopausal women) are recommended in patients subjected to TSH suppression for long periods of time. Finally, if the TSH suppression persists, in addition to their usual therapeutic indications, beta-blockers must be considered in patients with heart symptoms or morphological alterations, as well as the use of bisphosphonates in postmenopausal women with osteopenia $(57,58)$.

To avoid long periods outside the target, it is recommended to measure TSH levels 6 to 8 weeks after the onset of replacement therapy or after any change in the dose or commercial formulation of T4 and every six months once the desired levels are achieved, provided the dose is kept unchanged.

\section{Recommendation 50}

The level of TSH suppression must be individualized according to the ongoing disease state (Recommendation B). Measures to monitor and prevent the negative effects of TSH suppression must be applied to patients subjected to TSH suppression for long periods of time (Recommendation B).

\section{What are the recommendations relative to the method for thyroglobulin measurement?}

Measurement of Tg is not a trivial laboratory exam (135). Although a number of limitations are minimized by highly sensitive immunometric methods, others remain (135):

1. Lack of international standards, resulting in variability of the available methods.

2. Excessively high inter-assay variability, especially when we consider the usual interval between sample collections during the follow up of patients with differentiated carcinoma (6 to 12 months). Therefore, to reduce the inter-assay error, the laboratories should keep samples frozen for at least one year to process the older sample together with the newer one.

3. Possibility of a "hook effect", especially in the immunometric assays, leading to inappropriately low results in patients with very high $\mathrm{Tg}$ levels. To avoid this effect, the tests should be systematically performed in two steps.

4. The presence of $\mathrm{TgAb}$ in the serum can elicit false low $\mathrm{Tg}$ results in immunometric assays (136). Therefore, investigation of $\mathrm{TgAb}$ is mandatory, 
and whenever positive, the laboratory must call attention to the possibility of false-negative $\mathrm{Tg}$ results. In such cases, quantitative investigation of serum $\mathrm{Tg}$ mRNA may be an alternative (137); however, it is not yet available in clinical practice.

\section{What is the recommendation for the initial assessment of patients who were not given ${ }^{131} \mid$ ?}

\section{Recommendation 51}

For very low-risk patients not subjected to treatment with ${ }^{131} \mathrm{I}$, it is recommended to measure $\mathrm{Tg}$ [T4] and $\mathrm{TgAb}$ levels and to perform a neck US six months after thyroidectomy. The patients with serum Tg [T4] levels $\leq \mathrm{lng} / \mathrm{ml}$, no $\mathrm{TgAb}$, and no abnormal findings on US are considered to be disease free; therefore, the measurement of stimulated Tg is not needed (Recommendation B). When Tg [T4] levels are higher than 1 $\mathrm{ng} / \mathrm{ml}$, or the $\mathrm{TgAb}$ assay is positive, patient management will depend on the behavior of these markers, i.e., a more thorough investigation (in case of increase) or only monitoring (in case of decrease) (Recommendation B).

\section{What exams must be performed at the initial assessment following ablation?}

In the patients in whom WBS after RAI treatment does not show ectopic uptake, six months after ablation, measurement of $\mathrm{Tg}$ [T4] and TgAb levels and neck US are recommended.

At that moment, most patients exhibit Tg [T4] levels $\leq \mathrm{lng} / \mathrm{ml}$, a negative $\mathrm{TgAb}$, and no abnormal findings on US. In that case, stimulated Tg ought to be measured 9 to 12 months after ablation (138-140). Ultrasensitive Tg tests (functional sensitivity $\leq 0.2 \mathrm{ng} / \mathrm{ml}$ ) are available in Brazil and may reduce the need to measure stimulated $\mathrm{Tg}$ (141). Indeed, when Tg is measured using these tests, stimulation becomes unnecessary in low-risk patients with undetectable $\mathrm{Tg}$ [T4] levels, no TgAc interference, and negative US findings (141-145). Diagnostic WBS concomitant with stimulated Tg may be helpful in intermediate- or high-risk patients (140); however, its value has not been established (138).

In the patients with undetectable $\mathrm{Tg}$ [T4] levels and negative US findings but circulating TgAb, stimulated Tg associated with diagnostic WBS may be useful (146). However, if TgAb was assessed earlier, usually at the time of ablation, and the ongoing levels show a reduction of $>50 \%$ of their titer (147), neither stimulated $\mathrm{Tg}$ nor diagnostic WBS are necessary.
To avoid stunning, diagnostic WBS must be performed with ${ }^{123} \mathrm{I}, 2 \mathrm{mCi}$ of ${ }^{131} \mathrm{I}$ (148), or tracer activity of $5 \mathrm{mCi}$ of ${ }^{131} \mathrm{I}$, provided that the ${ }^{131} \mathrm{I}$ therapy (whenever necessary) is performed 3 to 5 days later (149).

TSH levels $>30 \mathrm{mIU} / \mathrm{ml}$ are necessary to accomplish appropriate $\mathrm{Tg}$ stimulation and WBS and are achieved by a total ( 3 to 4 weeks) or partial ( 6 to 8 weeks) discontinuation of T4 (150) or administration of recombinant TSH. When hypothyroidism is contraindicated or endogenous TSH is unable to increase to appropriate levels, use of recombinant TSH is the only available option. In the remainder of cases, due to the above-mentioned advantages, use of recombinant TSH is systematically preferred, when available.

For the purpose of $\mathrm{Tg}$ stimulation, one ampoule $(0.9 \mathrm{mg})$ of TSH is administered intramuscularly on two consecutive days; the Tg levels should be measured 72 hours after the second dose.

\section{Recommendation 52}

Measurement of serum Tg [T4] and TgAb levels and a neck US must be performed six months following ablation. Stimulated $\operatorname{Tg}$ (9 to 12 months after ablation) is recommended when the earlier results were negative, except for low-risk patients with undetectable $\mathrm{Tg}$ [T4] levels on an ultrasensitive test and no $\operatorname{TgAb}$ interference (Recommendation B). Diagnostic WBS (associated with stimulated $\mathrm{Tg}$ ) may be useful in intermediate- or high-risk patients (Recommendation C).

\section{Recommendation 53}

In patients with undetectable $\mathrm{Tg}$ [T4] levels and a negative US but circulating $\mathrm{TgAb}$, stimulated $\mathrm{Tg}$ associated with a diagnostic WBS may be useful (Recommendation $\mathrm{C})$; however, those tests are not necessary when the $\mathrm{TgAb}$ titers decrease by $>50 \%$ (Recommendation $\mathrm{B}$ ).

\section{What is the recommended investigation in patients with high $\mathrm{Tg}$ and negative US?}

In patients with $\mathrm{Tg}$ [T4] levels $>1 \mathrm{ng} / \mathrm{ml}$ and a negative neck US, the initial step is to perform a chest and mediastinal CT. When no abnormalities are thus found, one may decide to merely monitor the $\mathrm{Tg}$ behavior later or to perform a more thorough investigation based on the $\mathrm{Tg}$ [T4] levels and the patient risk category. In the latter case, the traditional recommendation is to perform WBS after the use of radioiodine $\left(100 \mathrm{mCi}{ }^{131} \mathrm{I}\right)$ followed by ${ }^{18} \mathrm{FDG}$-PET 
$(139,151)$; however, the latter might also be the first step $(138,152,153)$.

When negative $\mathrm{Tg}$ [T4] levels increase to levels above $\mathrm{l} \mathrm{ng} / \mathrm{ml}$ following TSH-induced stimulation and metastases are not found at the initial assessment, conservative management is recommended when $\mathrm{Tg}$ is less than 10 $\mathrm{ng} / \mathrm{ml}$ following discontinuation of T4 or $5 \mathrm{ng} / \mathrm{ml}$ with use of recombinant TSH $(91,124,125,138)$. When the $\mathrm{Tg}$ levels are higher, a more thorough investigation is recommended, as mentioned above. Many patients with elevated $\mathrm{Tg}$ and no apparent disease progress late into complete remission $(91,112,124,125,138,151,152,154)$.

\section{Recommendation 54}

In patients with $\mathrm{Tg}$ [T4] levels greater than $1 \mathrm{ng} / \mathrm{ml}$ or stimulated $\mathrm{Tg}$ higher than $5 \mathrm{ng} / \mathrm{ml}$ (with recombinant TSH) or $10 \mathrm{ng} / \mathrm{ml}$ (under hypothyroidism), chest and mediastinal CT followed by WBS after an empirical dose (of $100 \mathrm{mCi}$ ) of ${ }^{131} \mathrm{I}$ and/or ${ }^{18} \mathrm{FDG}$-PET is recommended (Recommendation B).

\section{How should cervical lymphadenopathy be managed?}

US is the most sensitive method to detect neck metastases $(122,140,142,144,155)$; however, its sensitivity depends on the examiner's experience and ability (156). Lymph nodes larger than $5 \mathrm{~mm}$ must be investigated only when they exhibit micro-calcifications or cystic degeneration or, in the absence of these findings, if they are round and lack an echogenic hilum or are hypervascular based on Doppler results $(98,140,157$ 160). FNA is crucial to establish the nature of suspicious lymph nodes; therefore, the biopsied tissue must be subjected to cytological analysis and Tg should be measured in the needle washing fluid $(158,160)$.

\section{Recommendation 55}

US is the best method to assess neck lymph nodes. Cytological analysis of the FNA material and measurement of $\mathrm{Tg}$ in the aspirated fluid are recommended in suspicious lymph nodes (Recommendation B).

\section{How should patients who achieve complete remission after treatment be monitored?}

\section{Recommendation 56}

The patients who achieve complete remission (undetectable $\mathrm{Tg}$, no $\mathrm{TgAb}$, and negative findings on the imaging methods) following treatment are at low risk of relapse in the long term $(87,90,91,112,138,143)$. Therefore, these patients may be assessed once per year by means of a clinical examination and measurement of serum $\mathrm{Tg}$ [T4] and $\mathrm{TgAb}$ levels (Recommendation B). Neck US must be performed annually the first five years in intermediate- or high-risk patients, whereas it is optional or may be performed at longer intervals in low-risk patients (Recommendation B). The long-term recommended TSH levels are shown in Figure 2. In case $\mathrm{TgAb}$ or $\mathrm{Tg}$ [T4] levels become persistently detectable, and more particularly, when they exhibit progressive increase, and US shows no abnormal findings, investigation must include other imaging methods such as chest and mediastinal CT, WBS after RAI treatment, or FDG-PET (Recommendation B). The need to repeat stimulated $\mathrm{Tg}$ in patients who maintain negative findings of $\mathrm{Tg}$ [T4], $\mathrm{TgAb}$, and US is doubtful. If it is, indeed, performed, it should not be too soon after the first negative stimulated Tg test [i.e., < five years (161)].

\section{Recommendation 57}

In the cases where only the $\mathrm{TgAb}$ are elevated, an annual measurement of $\mathrm{Tg}$ [T4] and TgAb levels and the performance of the US are recommended (Recommendation B). Abnormalities on the US, the persistent and progressive increase of $\mathrm{TgAb}$ titers, and elevated $\mathrm{Tg}$ [T4] levels point to tumor recurrence, indicating the need for further investigation by means of other imaging methods (Recommendation B). Conversely, disappearance of $\operatorname{TgAb}$ with undetectable $\mathrm{Tg}$ [T4] and negative US findings are indicative of remission (Recommendation B).

How should the patients with elevated thyroglobulin without apparent disease at the initial assessment be monitored?

\section{Recommendation 58}

When the initial assessment does not reveal disease, monitoring by means of serum $\mathrm{Tg}$ [T4] and $\mathrm{TgAb} 1$ levels, a neck US, and maintenance of TSH suppression (Figure 2) are recommended. In the cases where elevated stimulated Tg is the only finding, a second test is recommended 18-24 months later. Whenever Tg increases, the clinical investigation must be furthered (chest and mediastinal CT, WBS following the use of an empirical ${ }^{131}$ I dose, FDG-PET). As long as Tg levels are stable or decreasing, no further investigation is needed, and 
the clinical outcome will be most likely be satisfactory $(91,112,124,138,151,154)$. Finally, the patients with undetectable stimulated $\mathrm{Tg}$ should be monitored as if they were in complete remission (Recommendation B).

\section{Metastatic disease}

When surgical treatment and ${ }^{131} \mathrm{I}$ therapy associated with TSH suppression $(\leq 0.1 \mathrm{mIU} / \mathrm{L})(162)$ do not suffice to control metastatic disease, external radiotherapy should be considered depending on the site. Conventional chemotherapy has proven to induce a limited benefit but considerable morbidity in patients with progressive disease, in spite of the measures described above (163). New therapeutic approaches based on molecular targeted therapies are currently emerging as promising alternatives in such cases $(164,165)$. However, the recommendation to use those new drugs in clinical practice must be cautious, as a large number of the new drugs are still under investigation and their availability is limited. In addition, their high cost and significant side effects (heart, gastrointestinal, and skin) must be considered. Whether synergistic drug combinations exhibit better cost-benefit ratios and less morbidity remains to be determined (166).

\section{What is the approach for local-regional disease?}

Five to $20 \%$ of patients with DTC exhibit local or regional recurrence, which is approximately twice the frequency of the distant metastases $(67,72,167)$.

The most widely indicated treatment of local-regional disease is surgical excision, especially in the absence of distant metastases. Most surgeons recommend extending the exploration beyond the apparently affected compartments because the extent of the metastatic disease tends to be larger than suggested by the imaging exams, but this exploration should preserve the vital structures (168). Approximately $30-50 \%$ of the patients attain complete remission shortly after surgical reintervention (169).

In recent years, US-guided percutaneous ethanol injection of metastatic lymph nodes has emerged as a therapeutic possibility for patients with papillary carcinoma and a limited number of metastases $(170,171)$.

In tumors that invade the upper airway and/or digestive tract, aggressive surgery seeking to resect as much affected tissue as possible, while preserving organ function is recommended. Surgery may include tracheal resection with anastomosis or esophagopharyngectomy (172).

\section{Recommendation 59}

Therapeutic dissection is indicated in metastases located in the central compartment; and careful pre- and perioperative assessment is required to define the extent of the procedure in the lateral compartments (Recommendation B). Therapeutic dissection is indicated in metastases located in the lateral compartments (Recommendation B), and dissection of the central compartment lymph nodes is also indicated when it was not performed initially (Recommendation B).

\section{Recommendation 60}

When surgical resection is not complete or possible, and the tumor has ${ }^{131}$ I uptake, the patient should be subjected to treatment with ${ }^{131} \mathrm{I}$ (Recommendation B).

In patients treated with ${ }^{131} \mathrm{I}$, lack of ectopic uptake on WBS after treatment, associated with negative stimulated Tg is predictive of low risk of relapse (173).

\section{Recommendation 61}

Whenever it is technically possible, extensive surgery is indicated for tumors that invade the upper airway and/ or digestive tract, provided that the surgery can be performed by surgeons with broad experience in these procedures and reinterventions and can subsequently be combined with radioactive iodine therapy when the tumor demonstrates ${ }^{131}$ I uptake (Recommendation B).

\section{Recommendation 62}

External radiotherapy is indicated in patients with clinically significant, non-resectable, local-regional disease without ${ }^{131}$ I uptake (Recommendation B).

\section{Distant metastases: general considerations}

The patients with DTC and distant metastases exhibit increased mortality and morbidity $(67,72)$. Nevertheless, the negative impact of metastases depends on their number, localization, and size as well as on the patient age and tumor ${ }^{131}$ I uptake $(174,175)$. Whenever metastases are resectable, surgery is the treatment of choice, provided its associated morbidity is acceptable. In this regard, it is advisable for the procedure to be performed by a surgeon with wide experience in major surgery and reinterventions. The procedure must be aggressive, while seeking to preserve organ function. In this regard, the indication for highly aggressive surgical procedures that compromise the overall state of 
the patients without likelihood of curing them, or in the presence of multiple additional metastases, must be questioned.

\section{What is the approach in patients with lung metastases?}

The treatment of lung macrometastases with ${ }^{131} \mathrm{I}$ uptake is similar to the treatment of micrometastases. However, as the ${ }^{131}$ I uptake is not adequate in such tumors, therapeutic alternatives must be taken into consideration, such as surgical resection of the metastases, which must be performed whenever possible; palliative external radiotherapy in symptomatic intrathoracic tumors; drainage of symptomatic pleural or pericardial effusions; tumor redifferentiation attempts (178); or use of the novel molecular-targeted drugs, which appear to induce better responses specifically in lung metastases $(179,180)$.

Traditional chemotherapy has not proven to be useful in patients with non-resectable tumors that do not exhibit ${ }^{131}$ I uptake (163).

\section{Recommendation 63}

Patients with lung micro- or macrometastases that demonstrate ${ }^{131}$ I uptake must be given 100 to $200 \mathrm{mCi}$ of ${ }^{131}$ I every 6 months during the first two years and then once per year. Most remissions occur at an accumulated activity $\leq 600 \mathrm{mCi}$. Above this level, the eventual benefit of additional radioactive iodine therapy must be balanced with its potential risks (Recommendation B).

\section{Recommendation 64}

A large number of patients with lung macrometastases kept under suppressed TSH levels $(\leq 0.1 \mathrm{mIU} / \mathrm{L})$ have a good outcome and can be monitored in a conservative manner (Recommendation B). Other cases of lung macrometastases exhibit a more aggressive progression, and thus the palliative treatment of symptomatic lesions must be considered, including surgical resection, external radiotherapy, and endobronchial laser ablation (Recommendation B).

\section{Recommendation 65}

Patients with progressive or symptomatic lung metastatic disease that is not responsive to conventional treatment should be encouraged to enroll in clinical trials for new drugs when available. For patients not included in clinical trials, the off-label use of drugs commercially availa- ble for other malignant tumors and previously investigated in DTC may be considered (Recommendation C).

\section{What is the approach in patients with bone metastases?}

Up to $40 \%$ of the patients with DTC and distant metastases exhibit bone involvement, which is associated with a poorer prognosis (176). The survival of the patients with bone metastases is usually reduced due to the therapeutic challenge posed by the localization and extent of the lesions, which usually do not exhibit ${ }^{131} \mathrm{I}$ uptake. In addition to the lower survival rates, the development of bone metastases may result in significant morbidity due to pathologic fractures, intense pain, immobility, and reduced quality of life (181). In clinical studies, the term skeletal-related events (SRE) is used to quantify the morbidity associated with bone metastases (181). The clinical determinants that compose the SRE include spinal cord compression, pathologic fractures, and the need for external radiotherapy or surgery to afford pain relief or control tumor-related hypercalcemia (181). The patients frequently exhibit pathologic fractures that can involve the vertebrae, resulting in severe neurological problems, including disabling pain and paraplegia (182).

In addition to the clinical data, imaging resources are crucial to identify the presence, location, and extent of the bone lesions; skeletal CT or MRI and FDGPET/CT are the best currently available methods for this purpose (176).

When the number of bone metastases is limited, surgical resection significantly improves patient prognosis and survival and may eventually also be curative $(176,183,184)$. Bone lesions that exhibit ${ }^{131}$ I uptake are also associated with improved survival $(176,184)$. The recommended ${ }^{131} \mathrm{I}$ activity varies from 150 to $200 \mathrm{mCi}$ per cycle. In tumors located in critical areas close to neural structures, ${ }^{131}$ I-induced edema can cause nerve compression associated with severe pain and functional disability (182). In such cases, external radiotherapy combined with corticosteroids must be considered $(176,182)$. Radiotherapy is also indicated for non-resectable metastases that do not exhibit ${ }^{131}$ I uptake. Other procedures such as intra-arterial embolization, periodic pamidronate or zoledronate infusions, or cement injections may also be useful $(185,186)$.

Selumetinib - a MEKL and MEK2 inhibitor represents a recent perspective in the treatment of 
bone metastases, which appear to be more resistant to tyrosine kinase inhibitors; this drug significantly increases ${ }^{131}$ I uptake and reverts the refractoriness to ${ }^{131} \mathrm{I}(165)$.

\section{Recommendation 66}

Bone metastases must be subjected to surgical treatment whenever possible. The treatment of non-resectable bone lesions that have ${ }^{131} \mathrm{I}$ uptake consists of the administration of 150 or $200 \mathrm{mCi}^{131} \mathrm{I}$ per cycle. These therapeutic approaches improve patient quality of life and survival (Recommendation B).

\section{Recommendation 67}

In areas where the expansion of bone metastases induced by ${ }^{131}$ I or high TSH levels may cause neurological complications or pain, corticosteroid use is recommended (Recommendation B).

\section{Recommendation 68}

External radiotherapy is recommended for non-resectable metastases that are painful or symptomatic and are located in sites where the ${ }^{131} \mathrm{I}$-induced expansion is problematic or where they do not demonstrate ${ }^{131} \mathrm{I}$ uptake (Recommendation B).

\section{Recommendation 69}

Patients with progressive or symptomatic bone metastatic disease non-responsive to conventional treatment must be encouraged to enroll in clinical trials of new drugs when they are available (Recommendation C).

\section{What is the approach for brain metastases?}

Brain metastases are rare complications of DTC and occur more frequently among older adults with advanced stages of the disease. Nevertheless, these lesions may be the first manifestation or the first metastasis of thyroid cancer (187). Imaging exams such as CT and gadolinium-based MRI (preferably) are usually able to reveal the tumor location and extent. A biopsy is frequently necessary to confirm that a lesion is a thyroid cancer metastasis (188). Initial treatment is surgical and must attempt a full resection of the metastases, as a full resection is associated with improved survival $(187,188)$. These lesions do not usually exhibit ${ }^{131}$ I uptake, and treatment must thus include external radiotherapy or target-directed therapy (189).

\section{Recommendation 70}

The treatment of choice for brain metastases is the full surgical resection of the lesions (Recommendation $\mathrm{B})$. As the lesions often do not exhibit ${ }^{131}$ I uptake, external radiotherapy is indicated when surgery is not possible (Recommendation B), or the use of novel drugs must be considered, as indicated in $\mathbf{R} 6 \mathbf{5}$ (Recommendation C).

\section{When should recombinant TSH be used in metastatic disease?}

The possible use of recombinant TSH in the treatment of metastases that have ${ }^{131}$ I uptake has been assessed, and the response was seemingly similar to T4 withdrawal $(182,190,191)$. A retrospective study showed that the five-year survival rate was similar in patients with lung or bone metastases prepared with either T4 withdrawal or recombinant TSH before ${ }^{131}$ I therapy (190).

\section{Recommendation 71}

In the treatment of metastases with ${ }^{131} \mathrm{I}$, preparation with recombinant TSH is indicated in patients presenting with clinical conditions that contraindicate discontinuation of T4 (and the consequent hypothyroidism), who are unable to increase the endogenous TSH to satisfactory levels, are very debilitated, or old (Recommendation B). Pre-treatment with corticosteroids is recommended in metastatic sites where the risk of expansion due to edema and bleeding might be problematic (Recommendation B).

Acknowledgements: we would like to thank Dra. Carmen Cabanelas Pazos de Moura, President of the Thyroid Department of the Brazilian Society of Endocrinology \& Metabolism, for her support of this study.

Disclosure: no potential conflict of interest relevant to this article was reported.

\section{References}

1. Vander JB, Gaston EA, Dawber TR. The significance of nontoxic thyroid nodules. Final report of a 15-year study of the incidence of thyroid malignancy. Ann Intern Med. 1968;69:537-40.

2. Tunbridge WM, Evered DC, Hall R, Appleton D, Brewis M, Clark F, et al. The spectrum of thyroid disease in a community: the Whickham survey. Clin Endocrinol (Oxf). 1977;7:481-93.

3. Tan GH, Gharib H. Thyroid incidentalomas: management approaches to nonpalpable nodules discovered incidentally on thyroid imaging. Ann Intern Med. 1997;126:226-31. 
4. Guth S, Theune U, Aberle J, Galach A, Bamberger CM. Very high prevalence of thyroid nodules detected by high frequency (13 $\mathrm{MHz}$ ) ultrasound examination. Eur J Clin Invest. 2009;39:699-706.

5. Hegedus L. The thyroid nodule. N Engl J Med. 2004;351:1764-71.

6. Davies $L$, Welch HG. Increasing incidence of thyroid cancer in the United States, 1973-2002. JAMA. 2006;295:2164-7.

7. Veiga LH, Neta G, Aschebrook-Kilfoy B, Ron E, Devesa SS. Thyroid cancer incidence patterns in São Paulo, Brazil and the U.S. SEER program, 1997-2008. Thyroid 2013 (in press).

8. Instituto Nacional do Câncer José Alencar Gomes da Silva (INCA). Síntese de resultados e comentários: câncer da glândula tireoide. Estimativa 2012: incidência de câncer no Brasil. Available at: http://www.inca.gov.br/estimativa/2012. Access: May 31, 2013.

9. Projeto Diretrizes. Associação Médica Brasileira e Conselho Federal de Medicina. Available at: http://www.projetodiretrizes.org. br/projeto_diretrizes/texto_introdutorio.pdf. Access: May 31, 2013.

10. Tronko MD, Howe GR, Bogdanova TI, Bouville AC, Epstein OV, Brill $A B$, et al. A cohort study of thyroid cancer and other thyroid diseases after the chornobyl accident: thyroid cancer in Ukraine detected during first screening. J Natl Cancer Inst. 2006;98:897903.

11. Raza SN, Shah MD, Palme CE, Hall FT, Eski S, Freeman JL. Risk factors for well-differentiated thyroid carcinoma in patients with thyroid nodular disease. Otolaryngol Head Neck Surg. 2008;139:21-6.

12. Rago T, Fiore E, Scutari M, Santini F, Di Coscio G, Romani R, et al. Male sex, single nodularity, and young age are associated with the risk of finding a papillary thyroid cancer on fine-needle aspiration cytology in a large series of patients with nodular thyroid disease. Eur J Endocrinol. 2010;162:763-70.

13. Rosario PW, Mineiro Filho AF, Prates BS, Silva LC, Lacerda RX, Calsolari MR. Ultrasonographic screening for thyroid cancer in siblings of patients with apparently sporadic papillary carcinoma. Thyroid. 2012;22:805-8.

14. Soelberg KK, Bonnema SJ, Brix TH, Hegedüs L. Risk of malignancy in thyroid incidentalomas detected by (18)F-Fluorodeoxyglucose Positron Emission Tomography: a systematic review. Thyroid. 2012;22:918-25.

15. Wong CK, Wheeler MH. Thyroid nodules: rational management. World J Surg. 2000;24:934-41.

16. Anil C, Goksel S, Gursoy A. Hashimoto's thyroiditis is not associated with increased risk of thyroid cancer in patients with thyroid nodules: a single-center prospective study. Thyroid. 2010;20:6016.

17. Boelaert K, Horacek J, Holder RL, Watkinson JC, Sheppard MC, Franklyn JA. Serum thyrotropin concentration as a novel predictor of malignancy in thyroid nodules investigated by fine-needle aspiration. J Clin Endocrinol Metab. 2006;91:4295-301.

18. Haymart MR, Repplinger DJ, Leverson GE, Elson DF, Sippel RS, Jaume JC, et al. Higher serum thyroid stimulating hormone level in thyroid nodule patients is associated with greater risks of differentiated thyroid cancer and advanced tumor stage. J Clin Endocrinol Metab. 2008;93:809-14.

19. Niccoli P, Wion-Barbot N, Caron P, Henry JF, de Micco C, Saint Andre JP, et al. Interest of routine measurement of serum calcitonin: study in a large series of thyroidectomized patients. The French Medullary Study Group. J Clin Endocrinol Metab. 1997;82:338-41.

20. Elisei R, Bottici V, Luchetti F, Di Coscio G, Romei C, Grasso L, et al. Impact of routine measurement of serum calcitonin on the diagnosis and outcome of medullary thyroid cancer: experience in 10,864 patients with nodular thyroid disorders. J Clin Endocrinol Metab. 2004;89:163-8.

21. Papi G, Corsello SM, Cioni K, Pizzini AM, Corrado S, Carapezzi C, et al. Value of routine measurement of serum calcitonin concen- trations in patients with nodular thyroid disease: a multicenter study. J Endocrinol Invest. 2006;29:427-37.

22. Rosario PW, Penna GC, Brandão K, Souza BE. Usefulness of preoperative serum calcitonin in patients with nodular thyroid disease without suspicious history or cytology for medullary thyroid carcinoma. Arq Bras Endocrinol Metabol. 2013 (in press).

23. Pacini F, Pinchera A, Giani C, Grasso L, Doveri F, Baschieri L. Serum thyroglobulin in thyroid carcinoma and other thyroid disorders. J Endocrinol Invest. 1980;3:283-92.

24. Hegedus L. Thyroid ultrasound. Endocrinol Metab Clin North Am. 2001;30:339-60.

25. Marqusee E, Benson CB, Frates MC, Doubilet PM, Larsen PR, Cibas $E S$, et al. Usefulness of ultrasonography in the management of nodular thyroid disease. Ann Intern Med. 2000;133:696-700.

26. Shimamoto $K$, Satake $H$, Sawaki $A$, Ishigaki T, Funahashi $H$, Imai T. Preoperative staging of thyroid papillary carcinoma with ultrasonography. Eur J Radiol. 1998;29:4-10.

27. Peccin S, de Castro JA, Furlanetto TW, Furtado AP, Brasil BA, Czepielewski MA. Ultrasonography: is it useful in the diagnosis of cancer in thyroid nodules? J Endocrinol Invest. 2002;25:39-43.

28. Tomimori EK, Bisi H, Medeiros-Neto G, Camargo RY. Ultrasonographic evaluation of thyroid nodules: comparison with cytologic and histologic diagnosis. Arq Bras Endocrinol Metabol. 2004;48:105-13.

29. Cappelli C, Pirola I, Cumetti D, Micheletti L, Tironi A, Gandossi $\mathrm{E}$, et al. Is the anteroposterior and transverse diameter ratio of nonpalpable thyroid nodules a sonographic criteria for recommending fine-needle aspiration cytology? Clin Endocrinol (Oxf). 2005;63:689-93.

30. Chammas MC, Gerhard R, de Oliveira IR, Widman A, de Barros N, Durazzo M, et al. Thyroid nodules: evaluation with power Doppler and duplex Doppler ultrasound. Otolaryngol Head Neck Surg. 2005;132:874-82.

31. Rosario PW, Salles DS, Purisch S. Fine-needle biopsy should be performed in solid hypoechoic thyroid nodules greater than one centimeter even in the absence of suspicious ultrasonographic characteristics. Thyroid. 2010;20:939-40.

32. Russ G, Royer B, Bigorgne C, Rouxel A, Bienvenu M, Leenhardt L. Prospective evaluation of thyroid imaging reporting and data system (TI-RADS) on 4550 nodules with and without elastography. Eur J Endocrinol. 2013;168:649-55.

33. Oliver $\mathrm{C}$, Vaillant-Lombard J, Albarel F, Berbis J, Veyrières JB, Sebag $F$, et al. What is the contribution of elastography to thyroid nodules evaluation? Ann Endocrinol (Paris). 2011;72:120-4.

34. Jennings A. Evaluation of substernal goiters using computed tomography and MR imaging. Endocrinol Metab Clin North Am. 2001;30:401-14.

35. Vriens D, de Wilt JH, van der Wilt GJ, Netea-Maier RT, Oyen WJ, de Geus-Oei LF. The role of [18F]-2-fluoro-2-deoxy-d-glucose-positron emission tomography in thyroid nodules with indeterminate fine-needle aspiration biopsy: systematic review and metaanalysis of the literature. Cancer. 2011;117:4582-94.

36. Shambaugh GE 3rd, Quinn JL, Oyasu R, Freinkel N. Disparate thyroid imaging. Combined studies with sodium pertechnetate Tc 99m and radioactive iodine. JAMA. 1974;228:866-9.

37. Rosário PW, Salles DS, Bessa B, Purisch S. Contribution of scintigraphy and ultrasonography to the prediction of malignancy in thyroid nodules with indeterminate cytology. Arq Bras Endocrinol Metabol. 2010;54:56-9.

38. Rosario PW, Salles DS, Bessa B, Purisch S. Low false-negative rate of cytology in thyroid nodules $>4 \mathrm{~cm}$. Arq Bras Endocrinol Metabol. 2009;53:1143-5.

39. Matos PS, Ferreira APC, Ward LS. Prevalence of papillary microcarcinoma of the thyroid in Brazilian autopsy and surgical series. Endocr Pathol. 2006;17:165-74. 
40. Ito Y, Miyauchi A, Inoue H, Fukushima M, Kihara M, Higashiyama $\mathrm{T}$, et al. An observational trial for papillary thyroid microcarcinoma in Japanese patients. World J Surg. 2010;34:28-35.

41. Sugitani I, Toda K, Yamada K, Yamamoto N, Ikenaga M, Fujimoto Y. Three distinctly different kinds of papillary thyroid microcarcinoma should be recognized: our treatment strategies and outcomes. World J Surg. 2010;34:1222-31.

42. Cibas ES, Ali SZ. The Bethesda system for reporting thyroid cytopathology. Thyroid. 2009;19:1159-65.

43. Kwak JY, Kim EK, Kim HJ, Kim MJ, Son EJ, Moon HJ. How to combine ultrasound and cytological information in decision making about thyroid nodules. Eur Radiol. 2009;19:1923-31.

44. Rosario PW, Purisch S. Ultrasonographic characteristics as a criterion for repeat cytology in benign thyroid nodules. Arq Bras Endocrinol Metabol. 2010;54:52-5.

45. Maia FF, Matos PS, Pavin EJ, Vassallo J, Zantut-Wittmann DE. Value of repeat ultrasound-guided fine-needle aspiration in thyroid nodule with a first benign cytologic result: impact of ultrasound to predict malignancy. Endocrine. 2011;40:290-6.

46. Matos PS, Ferreira AP, Facuri FO, Assumpção LVM, Metze K, Ward LS. Usefulness of HBME-1, cytokeratin 19 and galectin-3 immunostaining in the diagnosis of thyroid malignancy. Histopathology. 2005;47:391-401.

47. Saleh HA, Feng J, Tabassum F, Al-Zohaili O, Husain M, Giorgadze T. Differential expression of galectin-3, CK19, HBME1, and Ret oncoprotein in the diagnosis of thyroid neoplasms by fine needle aspiration biopsy. Cytojournal. 2009;6:18.

48. NikiforovYE, Ohori NP, Hodak SP, Carty SE, LeBeau SO, Ferris RL, et al. Impact of mutational testing on the diagnosis and management of patients with cytologically indeterminate thyroid nodules: a prospective analysis of 1056 FNA samples. J Clin Endocrinol Metab. 2011;96:3390-7.

49. Ferraz C, Eszlinger M, Paschke R. Current state and future perspective of molecular diagnosis of fine-needle aspiration biopsy of thyroid nodules. J Clin Endocrinol Metab. 2011;96:2016-26.

50. Shen R, Liyanarachchi S, Li W, Wakely PE Jr, Saji M, Huang J, et al. MicroRNA signature in thyroid fine needle aspiration cytology applied to "atypia of undetermined significance" cases. Thyroid. 2012;22:9-16.

51. Alexander EK, Kennedy GC, Baloch ZW, Cibas ES, Chudova D, Diggans $\mathrm{J}$, et al. Preoperative diagnosis of benign thyroid nodules with indeterminate cytology. N Engl J Med. 2012;367:705-15.

52. Mestman JH, Goodwin TM, Montoro MM. Thyroid disorders of pregnancy. Endocrinol Metab Clin North Am. 1995;24:41-71.

53. Moosa M, Mazzaferri EL. Outcome of differentiated thyroid cancer diagnosed in pregnant women. J Clin Endocrinol Metab. 1997;82:2862-6.

54. Castro MR, Caraballo PJ, Morris JC. Effectiveness of thyroid hormone suppressive therapy in benign solitary thyroid nodules: a meta-analysis. J Clin Endocrinol Metab. 2002;87:4154-9.

55. Sdano MT, Falciglia M, Welge JA, Steward DL. Efficacy of thyroid hormone suppression for benign thyroid nodules: meta-analysis of randomized trials. Otolaryngol Head Neck Surg. 2005;133:3916.

56. Yousef A, Clark J, Doi SA. Thyroxine suppression therapy for benign, non-functioning solitary thyroid nodules: a quality-effects meta-analysis. Clin Med Res. 2010;8:150-8.

57. Biondi B, Cooper DS. The clinical significance of subclinical thyroid dysfunction. Endocr Rev. 2008;29:76-131.

58. Souza Rosário PW, Borges MAR, Vasconcelos FP, Gatti MF, Purisch S, Padrão EL, et al. Safety of suppressive therapy with levothyroxine: effects on bone metabolism and cardiac function and morphology and potential benefits of the use of alendronate and [beta]-blockers. Endocrinologist. 2007;17:148-51.
59. Schrut GC, Miasaki FY, Paz-Filho G, Cavalcanti TC, Graf H, de Carvalho $\mathrm{GA}$. Changes associated with percutaneous ethanol injection in the treatment of thyroid nodules. Endocr Pathol. 2011;22:79-85.

60. Bonnema SJ, Fast S, Hegedüs L. Non-surgical approach to the benign nodular goiter: new opportunities by recombinant human TSH-stimulated 131I-therapy. Endocrine. 2011;40:344-53.

61. Graf H, Fast S, Pacini F, Pinchera A, Leung A, Vaisman M, et al. Modified-release recombinant human TSH (MRrhTSH) augments the effect of (131)I therapy in benign multinodular goiter: results from a multicenter international, randomized, placebo-controlled study. J Clin Endocrinol Metab. 2011;96:1368-76.

62. Albino CC, Mesa CO Jr, Olandoski M, Ueda CE, Woellner LC, Goedert CA, et al. Recombinant human thyrotropin as adjuvant in the treatment of multinodular goiters with radioiodine. J Clin Endocrinol Metab. 2005;90:2775-80.

63. Rosario PW, Salles DS, Bessa B, Purisch S. Nodular thyroid disease: natural history of nodules without an initial indication for cytology. Endocrinologist. 2010;20:243-4.

64. Chung J, Youk JH, Kim JA, Kwak JY, Kim EK, Ryu YH, et al. Initially non-diagnostic ultrasound-guided fine needle aspiration cytology of thyroid nodules: value and management. Acta Radiol. 2012;53:168-73.

65. Moon HJ, Kwak JY, ChoiYS, Kim EK. How to manage thyroid nodules with two consecutive non-diagnostic results on ultrasonography-guided fine-needle aspiration. World J Surg. 2012;36:58692.

66. Alexander EK, Hurwitz S, Heering JP, Benson CB, Frates MC, Doubilet PM, et al. Natural history of benign solid and cystic thyroid nodules. Ann Intern Med. 2003;138:315-8.

67. Mazzaferri EL, Kloos RT. Current approaches to primary therapy for papillary and follicular thyroid cancer. J Clin Endocrinol Metab. 2001;86:1447-63.

68. Ito Y, Tomoda C, Uruno T, Takamura Y, Miya A, Kobayashi K, et al. Preoperative ultrasonographic examination for lymph node metastasis: usefulness when designing lymph node dissection for papillary microcarcinoma of the thyroid. World J Surg. 2004;28:498-501.

69. King AD, Ahuja AT, To EW, Tse GM, Metreweli C. Staging papillary carcinoma of the thyroid: magnetic resonance imaging vs. ultrasound of the neck. Clin Radiol. 2000;55:222-6.

70. Koike E, Yamashita H, Noguchi S, Ohshima A, Watanabe S, Uchino $S$, et al. Bronchoscopic diagnosis of thyroid cancer with laryngotracheal invasion. Arch Surg. 2001;136:1185-9.

71. Padovani RP, KasamatsuTS, Nakabashi CC, Camacho CP, Andreoni DM, Malouf EZ, et al. One month is sufficient for urinary iodine to return to its baseline value after the use of water-soluble iodinated contrast agents in post-thyroidectomy patients requiring radioiodine therapy. Thyroid. 2012;22:926-30.

72. Schlumberger MJ. Papillary and follicular thyroid carcinoma. $N$ Engl J Med. 1998;338:297-306.

73. Baudin E, Travagli JP, Ropers J, Mancusi F, Bruno-Bossio G, Caillou B, et al. Microcarcinoma of the thyroid gland: the GustaveRoussy Institute experience. Cancer. 1998;83:553-9.

74. Rosario PW, Fagundes TA, Purisch S. Treatment of papillary microcarcinoma of the thyroid. Arq Bras Endocrinol Metabol. 2004;48:855-60.

75. Hay ID, Hutchinson ME, Gonzalez-Losada T, Mclver B, Reinalda $\mathrm{ME}$, Grant CS, et al. Papillary thyroid microcarcinoma: a study of 900 cases observed in a 60-year period. Surgery. 2008;144:980-7.

76. Grebe SK, Hay ID. Thyroid cancer nodal metastases: biologic significance and therapeutic considerations. Surg Oncol Clin N Am. 1996;5:43-63.

77. Kouvaraki MA, Shapiro SE, Fornage BD, Edeiken-Monro BS, Sherman SI, Vassilopoulou-Sellin R, et al. Role of preoperative 
ultrasonography in the surgical management of patients with thyroid cancer. Surgery. 2003;134:946-54; discussion 54-5.

78. Lundgren $\mathrm{Cl}$, Hall P, Dickman PW, Zedenius J. Clinically significant prognostic factors for differentiated thyroid carcinoma: a population-based, nested case-control study. Cancer. 2006;106:524-31.

79. Teixeira G, Teixeira T, Gubert F, Chikota H, Tufano R. The incidence of central neck micrometastatic disease in patients with papillary thyroid cancer staged preoperatively and intraoperatively as NO. Surgery. 2011;150:1161-7.

80. Chow SM, Law SC, Chan JK, Au SK, Yau S, Lau WH. Papillary microcarcinoma of the thyroid-prognostic significance of lymph node metastasis and multifocality. Cancer. 2003;98:31-40.

81. Wada N, Duh OY, Sugino K, Iwasaki H, Kameyama K, MimuraT, et al. Lymph node metastasis from 259 papillary thyroid microcarcinomas: frequency, pattern of occurrence and recurrence, and optimal strategy for neck dissection. Ann Surg. 2003;237:399-407.

82. Rosário PW, Fagundes TA, Padrão EL, Rezende LL, Barroso AL. Total thyroidectomy and lymph node dissection in patients with papillary thyroid carcinoma. Arch Surg. 2004;139:1385.

83. Filho JG, Kowalski LP. Postoperative complications of thyroidectomy for differentiated thyroid carcinoma. Am J Otolaryngol. 2004;25:225-30.

84. Dutenhefner SE, Marui S, Santos AB, Lima EU, Inoue M, Neto JD, et al. BRAF, a tool in the decision to perform elective neck dissection? Thyroid. 2013 (in press).

85. Joo JY, Park JY, Yoon YH, Choi B, Kim JM, Jo YS, et al. Prediction of occult central lymph node metastasis in papillary thyroid carcinoma by preoperative BRAF analysis using fine-needle aspiration biopsy: a prospective study. J Clin Endocrinol Metab. 2012;97:3996-4003.

86. Akslen LA, LiVolsi VA. Prognostic significance of histologic grading compared with subclassification of papillary thyroid carcinoma. Cancer. 2000;88:1902-8.

87. Leboulleux S, Rubino C, Baudin E, Caillou B, Hartl DM, Bidart JM, et al. Prognostic factors for persistent or recurrent disease of papillary thyroid carcinoma with neck lymph node metastases and/or tumor extension beyond the thyroid capsule at initial diagnosis. J Clin Endocrinol Metab. 2005;90:5723-9.

88. Randolph GW, Duh OY, Heller KS, LiVolsi VA, Mandel SJ, Steward $\mathrm{DL}$, et al. The prognostic significance of nodal metastases from papillary thyroid carcinoma can be stratified based on the size and number of metastatic lymph nodes, as well as the presence of extranodal extension. Thyroid. 2012;22:1144-52.

89. Arslan N, Ilgan S, Serdengecti M, Ozguven MA, Bayhan H, Okuyucu K, et al. Post-surgical ablation of thyroid remnants with high-dose (131)I in patients with differentiated thyroid carcinoma. Nucl Med Commun. 2001;22:1021-7.

90. Rosario PW, Mineiro Filho AF, Prates BS, Silva LC, Calsolari MR. Postoperative stimulated thyroglobulin of less than $1 \mathrm{ng} / \mathrm{ml}$ as a criterion to spare low-risk patients with papillary thyroid cancer from radioactive iodine ablation. Thyroid. 2012;22:1140-3.

91. Rosário PW, Borges MA, Alves MF, Purisch S, Padrão EL, Rezende $\mathrm{LL}$, et al. Follow-up of high-risk patients with differentiated thyroid cancer without persistent disease after initial therapy. Arq Bras Endocrinol Metabol. 2006;50:909-13.

92. TaylorT, Specker B, Robbins J, Sperling M, Ho M, Ain K, et al. Outcome after treatment of high-risk papillary and non-Hurthle-cell follicular thyroid carcinoma. Ann Intern Med. 1998;129:622-7.

93. Rosário PW, Borges MA, Valadão MM, Vasconcelos FP, Rezende LL, Padrão EL, et al. Is adjuvant therapy useful in patients with papillary carcinoma smaller than $2 \mathrm{~cm}$ ? Thyroid. 2007;17:1225-8.

94. Vaisman F, Shaha A, Fish S, Tuttle R. Initial therapy with either thyroid lobectomy or total thyroidectomy without radioactive iodine remnant ablation is associated with very low rates of structural disease recurrence in properly selected patients with differentiated thyroid cancer. Clin Endocrinol (Oxf). 2011;75:112-9.

95. Momesso DP, Vaisman F, Cordeiro de Noronha Pessoa CH, Corbo R, Vaisman M. Small differentiated thyroid cancer: Time to reconsider clinical management and treatment. Surg Oncol. 2012;21:257-62.

96. Hay ID. Management of patients with low-risk papillary thyroid carcinoma. Endocr Pract. 2007;13:521-33.

97. Rosário PW, Xavier AC, Calsolari MR. Value of postoperative thyroglobulin and ultrasonography for the indication of ablation and ${ }^{131}$ I activity in patients with thyroid cancer and low risk of recurrence. Thyroid. 2011;21:49-53.

98. Nascimento C, Borget I, Al Ghuzlan A, Deandreis D, Chami L, Travagli JP, et al. Persistent disease and recurrence in differentiated thyroid cancer patients with undetectable postoperative stimulated thyroglobulin level. Endocr Relat Cancer. 2011;18:R2940.

99. Vaisman A, Orlov S, Yip J, Hu C, Lim T, Dowar M, et al. Application of post-surgical stimulated thyroglobulin for radioiodine remnant ablation selection in low-risk papillary thyroid carcinoma. Head Neck. 2010;32:689-98.

100. Ibrahimpasic T, Nixon IJ, Palmer FL, Whitcher MM, Tuttle RM, Shaha A, et al. Undetectable thyroglobulin after total thyroidectomy in patients with low- and intermediate-risk papillary thyroid cancer- is there a need for radioactive iodine therapy? Surgery. 2012;152:1096-105.

101. Rosário PW, Barroso AL, Rezende LL, Padrão EL, Borges MA, Guimaraes $\mathrm{VC}$, et al. Testicular function after radioiodine therapy in patients with thyroid cancer. Thyroid. 2006;16:667-70.

102. Souza Rosário PW, Alvarenga Fagundes T, Villas-Boas Fagundes AS, Barroso AL, Lamego Rezende L, Lanza Padrão E, et al. Ovarian function after radioiodine therapy in patients with thyroid cancer. Exp Clin Endocrinol Diabetes. 2005;113:331-3.

103. Rosário PW, Borges MA, Purisch S. Preparation with recombinant human thyroid-stimulating hormone for thyroid remnant ablation with $131 \mathrm{l}$ is associated with lowered radiotoxicity. J Nucl Med. 2008;49:1776-82.

104. Rosário PW, Fagundes TA, Fagundes AV, Barroso AL, Rezende LL, Padrao EL, et al. Radioiodine therapy and age at menopause in patients with thyroid cancer. Clin Endocrinol (Oxf). 2006;64:225-6.

105. Rosário PW, Calsolari MR. Salivary and lacrimal gland dysfunction after remnant ablation with radioactive iodine in patients with differentiated thyroid carcinoma prepared with recombinant human TSH. Thyroid. 2013;23:617-9.

106. Rubino C, de Vathaire F, Dottorini ME, Hall P, Schvartz C, Couette $\mathrm{JE}$, et al. Second primary malignancies in thyroid cancer patients. Br J Cancer. 2003;89:1638-44.

107. Rosário PW, Fagundes TA, Rezende LL, Padrão EL, Borges MA, Barroso AL. Assessing hypothyroidism in the preparation of patients with thyroid cancer: cardiovascular risk, renal function, drug metabolism, persistence of elevated thyroid-stimulating hormone, and absence from work. Endocrinologist. 2006;16:25-9.

108. Mallick U, Harmer C, Yap B, Wadsley J, Clarke S, Moss L, et al. Ablation with low-dose radioiodine and thyrotropin alfa in thyroid cancer. N Engl J Med. 2012;366:1674-85.

109. Schlumberger M, Catargi B, Borget I, Deandreis D, Zerdoud S, Bridji B, et al. Strategies of radioiodine ablation in patients with low-risk thyroid cancer. N Engl J Med. 2012;366:1663-73.

110. Hugo J, Robenshtok E, Grewal R, Larson SM, Tuttle RM. Recombinant human TSH-assisted radioactive iodine remnant ablation in thyroid cancer patients at intermediate to high risk of recurrence. Thyroid. 2012;22:1007-15.

111. Rosário PW, Xavier AC, Calsolari MR. Recombinant human thyrotropin in thyroid remnant ablation with 131-iodine in high-risk patients. Thyroid. 2010;20:1247-52. 
112. Rosário PW, Mineiro Filho AF, Lacerda RX, Calsolari MR. Longterm follow-up of at least five years after recombinant human thyrotropin compared to levothyroxine withdrawal for thyroid remnant ablation with radioactive iodine. Thyroid. 2012;22:332-3.

113. Rosário PW, Salles DS, Purisch S. Area under the curve of TSH after levothyroxine withdrawal versus administration of recombinant human TSH (rhTSH): possible implications for tumor growth. Arq Bras Endocrinol Metabol. 2009;53:767-70.

114. Rosário PW, Mineiro Filho AF, Lacerda RX, Calsolari MR. Recombinant human TSH for thyroid remnant ablation with (131)I in children and adolescents with papillary carcinoma. Horm Res Paediatr. 2012;77:59-62.

115. Rosário PW, Reis JS, Barroso AL, Rezende LL, Padrão EL, Fagundes TA. Efficacy of low and high 131I doses for thyroid remnant ablation in patients with differentiated thyroid carcinoma based on post-operative cervical uptake. Nucl Med Commun. 2004;25:1077-81.

116. Barbaro D, Grosso M, Boni G, Lapi P, Pasquini C, Orsini P, et al. Recombinant humanTSH and ablation of post-surgical thyroid remnants in differentiated thyroid cancer: the effect of pre-treatment with furosemide and furosemide plus lithium. Eur $\mathrm{J}$ Nucl Med Mol Imaging. 2010;37:242-9.

117. Rosário PW, Xavier AC. Recombinant human thyroid stimulating hormone in thyroid remnant ablation with $1.1 \mathrm{GBq} 131$ iodine in low-risk patients. Am J Clin Oncol. 2012;35:101-4.

118. Yamazaki CA, Padovani R, Biscolla RP, Ikejri ES, Matsumura LK, Maciel RM, et al. Lithium as an adjuvant in the postoperative ablation of remnant tissue in low risk thyroid carcinoma. Thyroid. 2012;22:1002-6.

119. Rosário PW, Purisch S, Vasconcelos FP, Padrão EL, Rezende LL, Barroso AL. Long-term recurrence of thyroid cancer after thyroid remnant ablation with 1.1 and $3.7 \mathrm{GBq}$ radioiodine. Nucl Med Commun. 2007;28:507-8.

120. Tuttle RM, Leboeuf R, Robbins RJ, Qualey R, Pentlow K, Larson $\mathrm{SM}$, et al. Empiric radioactive iodine dosing regimens frequently exceed maximum tolerated activity levels in elderly patients with thyroid cancer. J Nucl Med. 2006;47:1587-91.

121. Sawka AM, Ibrahim-Zada I, Galacgac P, Tsang RW, Brierley JD, Ezzat $\mathrm{S}$, et al. Dietary iodine restriction in preparation for radioactive iodine treatment or scanning in well-differentiated thyroid cancer: a systematic review. Thyroid. 2010;20:1129-38.

122. Rosário PW, Guimarães VC, Maia FF, Fagundes TA, Purisch S, Padrão EL, et al. Thyroglobulin before ablation and correlation with posttreatment scanning. Laryngoscope. 2005;115:264-7.

123. Kendler DB, Vaisman F, Corbo R, Martins R, Vaisman M. Preablation stimulated thyroglobulin is a good predictor of successful ablation in patients with differentiated thyroid cancer. Clin Nucl Med. 2012;37:545-9.

124. Valadão MM, Rosário PW, Borges MA, Costa GB, Rezende LL, Padrão EL, et al. Positive predictive value of detectable stimulated $\mathrm{Tg}$ during the first year after therapy of thyroid cancer and the value of comparison with $\mathrm{Tg}$-ablation and $\mathrm{Tg}$ measured after 24 months. Thyroid. 2006;16:1145-9.

125. Toubeau M, Touzery C, Arveux P, Chaplain G, Vaillant G, Berriolo $A$, et al. Predictive value for disease progression of serum thyroglobulin levels measured in the postoperative period and after (131)I ablation therapy in patients with differentiated thyroid cancer. J Nucl Med. 2004;45:988-94.

126. Souza Rosário PW, Barroso AL, Rezende LL, Padrão EL, Fagundes TA, Penna GC, et al. Post I-131 therapy scanning in patients with thyroid carcinoma metastases: an unnecessary cost or a relevant contribution? Clin Nucl Med. 2004;29:795-8.

127. Rosário PW, Barroso AL, Rezende LL, Padrão EL, Reis JS, Purisch $S$, et al. Frequency of nonmetastatic (physiological) uptake on posttreatment scans in patients with differentiated thyroid carcinoma. Endocrinologist. 2007;17:78-82.

128. Rosário PW, Cardoso LD, Barroso A, Padrão EL, Rezende L, Purisch S. Consequences of the persistence of large thyroid remnants after bilateral thyroidectomy for differentiated thyroid cancer. Arq Bras Endocrinol Metabol. 2004;48:379-83.

129. Rosário P, Borges M, Reis J, Alves MF. Effect of suppressive therapy with levothyroxine on the reduction of serum thyroglobulin after total thyroidectomy. Thyroid. 2006;16:199-200.

130. Cooper DS, Specker B, Ho M, Sperling M, Ladenson PW, Ross DS, et al. Thyrotropin suppression and disease progression in patients with differentiated thyroid cancer: results from the $\mathrm{Na}$ tional Thyroid Cancer Treatment Cooperative Registry. Thyroid. 1998;8:737-44.

131. Jonklaas J, Sarlis NJ, Litofsky D, Ain KB, Bigos ST, Brierley JD, et al. Outcomes of patients with differentiated thyroid carcinoma following initial therapy. Thyroid. 2006;16:1229-42.

132. Hovens GC, Stokkel MP, Kievit J, Corssmit EP, Pereira AM, Romijn $\mathrm{JA}$, et al. Association of serum thyrotropin concentration with recurrence and death in differentiated thyroid cancer. J Clin Endocrinol Metab. 2007;92:2610-5.

133. Rosário PW. Bone and heart abnormalities of subclinical hyperthyroidism in women below the age of 65 years. Arq Bras Endocrinol Metabol. 2008;52:1448-51.

134. Martins de Almeida JF, Gonçalves Tsumura W, Vaisman M, Montalli Assumpção LV, Ward LS. Current recommendations for levothyroxine treatment of differentiated thyroid cancer patients are not properly implemented in a clinical practice. J Endocrinol Invest. 2012;35:901-4.

135. Maciel RM. O laboratório no diagnóstico e seguimento de doenças auto-imunes e neoplásicas de tiróide. Arq Bras Endocrinol Metabol. 2002;46:65-71.

136. Rosário PW, Maia FF, Fagundes TA, Vasconcelos FP, Cardoso LD, Purisch S. Antithyroglobulin antibodies in patients with differentiated thyroid carcinoma: methods of detection, interference with serum thyroglobulin measurement and clinical significance. Arq Bras Endocrinol Metabol. 2004;48:487-92.

137. Boldarine VT, Maciel RM, Guimarães GS, Nakabashi CC, Camacho $C P$, Andreoni DM, et al. Development of a sensitive and specific quantitative reverse transcription-polymerase chain reaction assay for blood thyroglobulin messenger ribonucleic acid in the follow-up of patients with differentiated thyroid carcinoma. J Clin Endocrinol Metab. 2010;95:1726-33.

138. Rosário PW, Furtado MD, Filho AF, Lacerda RX, Calsolari MR. Value of diagnostic radioiodine whole-body scanning after initial therapy in patients with differentiated thyroid cancer at intermediate and high risk for recurrence. Thyroid. 2012;22:1165-9.

139. Mazzaferri EL, Robbins RJ, Spencer CA, Braverman LE, Pacini F, Wartofsky $L$, et al. A consensus report of the role of serum thyroglobulin as a monitoring method for low-risk patients with papillary thyroid carcinoma. J Clin Endocrinol Metab. 2003;88:1433-41.

140. Pacini F, Molinaro E, Castagna MG, Agate L, Elisei R, Ceccarelli $C$, et al. Recombinant human thyrotropin-stimulated serum thyroglobulin combined with neck ultrasonography has the highest sensitivity in monitoring differentiated thyroid carcinoma. J Clin Endocrinol Metab. 2003;88:3668-73.

141. Maciel RM. Will the thyroglobulin assay with lower functional sensitivity whilst the patients are on L-T4 treatment replace theTSH-stimulated thyroglobulin assay in the follow-up of patients with differentiated thyroid cancer? Arq Bras Endocrinol Metabol. 2007;51:862-6.

142. Castagna MG, Tala Jury HP, Cipri C, Belardini V, Fioravanti C, Pasqui $L$, et al. The use of ultrasensitive thyroglobulin assays reduces but not abolishes the need for TSH stimulation in patients with differentiated thyroid carcinoma. J Endocrinol Invest. 2011;34:e219-23. 
143. Rosário PW, Purisch S. Does a highly sensitive thyroglobulin $(\mathrm{Tg})$ assay change the clinical management of low-risk patients with thyroid cancer with $\mathrm{Tg}$ on $\mathrm{T} 4<1 \mathrm{ng} / \mathrm{ml}$ determined by traditional assays? Clin Endocrinol. 2008;68:338-42.

144. lervasi A, lervasi G, Ferdeghini M, Solimeo C, Bottoni A, Rossi L, et al. Clinical relevance of highly sensitive Tg assay in monitoring patients treated for differentiated thyroid cancer. Clin Endocrinol. 2007;67:434-41.

145. Rosário PW, Mineiro Filho AF. Does undetectable basal Tg measured with a highly sensitive assay in the absence of antibodies and combined with normal ultrasonography ensure the absence of disease in patients treated for thyroid carcinoma? Arq Bras Endocrinol Metabol. 2012;56:149-51.

146. Rosário PW, Mineiro Filho AF, Lacerda RX, dos Santos DA, Calsolari MR. The value of diagnostic whole-body scanning and serum thyroglobulin in the presence of elevated serum thyrotropin during follow-up of anti-thyroglobulin antibody-positive patients with differentiated thyroid carcinoma who appeared to be free of disease after total thyroidectomy and radioactive iodine ablation. Thyroid. 2012;22:113-6.

147. Kim WG, Yoon JH, Kim WB, KimTY, Kim EY, Kim JM, et al. Change of serum antithyroglobulin antibody levels is useful for prediction of clinical recurrence in thyroglobulin-negative patients with differentiated thyroid carcinoma. J Clin Endocrinol Metab. 2008;93:4683-9.

148. Morris LF, Waxman AD, Braunstein GD. Thyroid stunning. Thyroid. 2003; 13:333-40.

149. Rosário PW, Barroso AL, Rezende LL, Padrão EL, Maia FF, Fagundes TA, et al. $5 \mathrm{mCi}$ pretreatment scanning does not cause stunning when the ablative dose is administered within 72 hours. Arq Bras Endocrinol Metabol. 2005;49:420-4.

150. Rosário PW, Vasconcelos FP, Cardoso LD, Lauria MW, Rezende LL, Padrão EL, et al. Managing thyroid cancer without thyroxine withdrawal. Arq Bras Endocrinol Metabol. 2006;50:91-6.

151. Rosário PW, Borges MA, Costa GB, Rezende LL, Padrão EL, Barroso $A L$, et al. Management of low-risk patients with thyroid carcinoma and detectable thyroglobulin on T4 after thyroidectomy and ablation with 131 iodine. Arq Bras Endocrinol Metab. 2007;51:99-103.

152. Kim WG, Ryu JS, Kim EY, Lee JH, Baek JH, Yoon JH, et al. Empiric high-dose 131-iodine therapy lacks efficacy for treated papillary thyroid cancer patients with detectable serum thyroglobulin, but negative cervical sonography and $18 \mathrm{~F}$-fluorodeoxyglucose positron emission tomography scan. J Clin Endocrinol Metab. 2010;95:1169-73.

153. Leboulleux S, El Bez I, Borget I, Elleuch M, Déandreis D, Al Ghuzlan A, et al. Postradioiodine treatment whole-body scan in the era of 18-fluorodeoxyglucose positron emission tomography for differentiated thyroid carcinoma with elevated serum thyroglobulin levels. Thyroid. 2012;22:832-8.

154. Vaisman F, Momesso D, Bulzico DA, Pessoa CH, Dias F, Corbo R, et al. Spontaneous remission in thyroid cancer patients after biochemical incomplete response to initial therapy. Clin Endocrinol. (Oxf). 2012;77:132-8.

155. Rosário PW, Fagundes TA, Maia FF, Franco AC, Figueiredo MB, Purisch S. Sonography in the diagnosis of cervical recurrence in patients with differentiated thyroid carcinoma. J Ultrasound Med. 2004;23:915-20;

156. Rosário PW. Ultrasonography for the follow-up of patients with papillary thyroid carcinoma: how important is the operator? Thyroid. 2010;20:833-4.

157. Rosário PW, de Faria S, Bicalho L, Alves MF, Borges MA, Purisch $S$, et al. Ultrasonographic differentiation between metastatic and benign lymph nodes in patients with papillary thyroid carcinoma. J Ultrasound Med. 2005;24:1385-9.
158. Biscolla RP, Ikejiri ES, Mamone MC, Nakabashi CCD, Andrade VP, Kasamatsu TS, et al. Diagnóstico de metástases de carcinoma diferenciado de tiróide através da dosagem de tiroglobulina no líquido obtido da lavagem da agulha utilizada na punção aspirativa. Arq Bras Endocrinol Metab. 2007;51:419-25.

159. Leboulleux S, Girard E, Rose M, Travagli JP, Sabbah N, Caillou B, et al. Ultrasound criteria of malignancy for cervical lymph nodes in patients followed up for differentiated thyroid cancer. J Clin Endocrinol Metab. 2007;92:3590-4.

160. Zanella AB, Meyer EL, Balzan L, Silva AC, Camargo J, Migliavacca $A$, et al. Thyroglobulin measurements in washout of fine needle aspirates in cervical lymph nodes for detection of papillary thyroid cancer metastases. Arq Bras Endocrinol Metabol. 2010;54:550-4.

161. Rosário PW, Furtado MS, Mineiro Filho AF, Lacerda RX, Calsolari $M R$. Value of repeat stimulated thyroglobulin testing in patients with differentiated thyroid carcinoma considered to be free of disease in the first year after ablation. Thyroid. 2012;22:482-6.

162. Filetti S, Tuttle RM, Sherman SI. Medical management of differentiated epithelial cell thyroid cancer. In: Braverman LE, Cooper DS. Werner \& Ingbar's The Thyroid: A Fundamental and Clinical Text. 10th Edition. Philadelphia: Lippincott Williams \& Wilkins; 2013.

163. Sherman SI. Cytotoxic chemotherapy for differentiated thyroid carcinoma. Clin Oncol (R Coll Radiol). 2010;22:464-8.

164. Nixon IJ, Shaha AR, Tuttle MR. Targeted therapy in thyroid cancer. Curr Opin Otolaryngol Head Neck Surg. 2013;21:130-4.

165. Ho AL, Grewal RK, Leboeuf R, Sherman EJ, Pfister DG, Deandreis $D$, et al. Selumetinib-enhanced radioiodine uptake in advanced thyroid cancer N Engl J Med. 2013;368:623-32.

166. Hong DS, Cabanillas ME, Wheler J, Naing A, Tsimberidou AM, Ye $\mathrm{L}$, et al. Inhibition of the Ras/Raf/MEK/ERK and RET kinase pathways with the combination of the multikinase inhibitor sorafenib and the farnesyltransferase inhibitor tipifarnib in medullary and differentiated thyroid malignancies. J Clin Endocrinol Metab. 2011;96:997-1005.

167. Schlumberger M, Pacini F. Local and regional recurrences. In: Schlumberger \& Pacini. ThyroidTumors. 3rd edition. Éditions Nucléon, Paris; 2006.

168. Uchino S, Noguchi S, Yamashita H, Watanabe S. Modified radical neck dissection for differentiated thyroid cancer: operative technique. World J Surg. 2004;28:1199-203.

169. Schuff KG. Management of recurrent/persistent papillary thyroid carcinoma: efficacy of the surgical option. J Clin Endocrinol Metab. 2011;96:2038-9.

170. Heilo A, Sigstad E, Fagerlid KH, Håskjold OI, Groholt KK, Berner $A$, et al. Efficacy of ultrasound-guided percutaneous ethanol injection treatment in patients with a limited number of metastatic cervical lymph nodes from papillary thyroid carcinoma. J Clin Endocrinol Metab. 2011;96:2750-5.

171. Hay ID, Charboneau JW. The coming of age of ultrasound-guided percutaneous ethanol ablation of selected neck nodal metastases in well-differentiated thyroid carcinoma. J Clin Endocrinol Metab. 2011;96:2717-20.

172. McCaffrey JC. Aerodigestive tract invasion by well-differentiated thyroid carcinoma: diagnosis, management, prognosis, and biology. Laryngoscope. 2006;116:1-11.

173. Bachelot A, Leboulleux S, Baudin E, Hartl DM, Caillou B, Travagli JP, et al. Neck recurrence from thyroid carcinoma: serum thyroglobulin and high-dose total body scan are not reliable criteria for cure after radioiodine treatment. Clin Endocrinol (Oxf). 2005;62:376-9.

174. Durante C, Haddy N, Baudin E, Leboulleux S, Hartl D, Travagli JP, et al. Long-term outcome of 444 patients with distant metastases from papillary and follicular thyroid carcinoma: benefits and lim- 
its of radioiodine therapy. J Clin Endocrinol Metab. 2006;91:28929.

175. Shoup M, Stojadinovic A, Nissan A, Ghossein RA, Freedman S, Brennan MF, et al. Prognostic indicators of outcomes in patients with distant metastases from differentiated thyroid carcinoma. J Am Coll Surg. 2003;197:191-7.

176. Schlumberger M, Pacini F. Distant Metastases. In: Schlumberger \& Pacini. Thyroid Tumors. 3rd edition. Paris: Éditions Nucléon, 2006.

177. Martins-Filho R, Ward LS, Amorim BJ, Santos AO, Lima MCL, Ramos $C D$,et al. Cumulative doses of radioiodine in the treatment of differentiated thyroid carcinoma: knowing when to stop. Arq Bras Endocrinol Metabol. 2010;54:807-12.

178. Coelho SM, Corbo R, Buescu A, Carvalho DP, Vaisman M. Retinoic acid in patients with radioiodine non-responsive thyroid carcinoma. J Endocrinol Invest. 2004;27:334-9.

179. Schneider TC, Abdulrahman RM, Corssmit EP, Morreau H, Smit JW, Kapiteijn E. Long-term analysis of the efficacy and tolerability of sorafenib in advanced radio-iodine refractory differentiated thyroid carcinoma: final results of a phase II trial. Eur J Endocrinol. 2012;167:643-50.

180. Cabanillas ME, Waguespack SG, Bronstein Y, Williams MD, Feng $L$, Hernandez $M$, et al. Treatment with tyrosine kinase inhibitors for patients with differentiated thyroid cancer: the M. D. Anderson experience. J Clin Endocrinol Metab. 2010;95:2588-95.

181. Farooki A, Leung V, Tala $H$, Tuttle RM. Skeletal-related events due to bone metastases from differentiated thyroid cancer. J Clin Endocrinol Metab. 2012;97:2433-9.

182. Luster M, Lippi F, Jarzab B, Perros P, Lassmann M, Reiners C, et al. rhTSH-aided radioiodine ablation and treatment of differentiated thyroid carcinoma: a comprehensive review. Endocr Relat Cancer. 2005;12:49-64.

183. Zettinig G, Fueger BJ, Passler C, Kaserer K, Pirich C, Dudczak R, et al. Long-term follow-up of patients with bone metastases from differentiated thyroid carcinoma - surgery or conventional therapy? Clin Endocrinol (Oxf). 2002;56:377-82.

184. Bernier MO, Leenhardt L, Hoang C, Aurengo A, Mary JY, Menegaux $F$, et al. Survival and therapeutic modalities in patients with bone metastases of differentiated thyroid carcinomas. J Clin Endocrinol Metab. 2001;86:1568-73.

185. Eustatia-Rutten CF, Romijn JA, Guijt MJ, Vielvoye GJ, van den Berg R, Corssmit EP, et al. Outcome of palliative embolization of bone metastases in differentiated thyroid carcinoma. J Clin Endocrinol Metab. 2003;88:3184-9.

186. Vitale G, Fonderico F, Martignetti A, Caraglia M, Ciccarelli A, Nuzzo $\mathrm{V}$, et al. Pamidronate improves the quality of life and induces clinical remission of bone metastases in patients with thyroid cancer. Br J Cancer. 2001;84:1586-90.

187. Chiu AC, Delpassand ES, Sherman SI. Prognosis and treatment of brain metastases in thyroid carcinoma. J Clin Endocrinol Metab. 1997; $82: 3637-42$.

188. McWilliams RR, Giannini C, Hay ID, Atkinson JL, Stafford SL, Buckner JC. Management of brain metastases from thyroid carcinoma: a study of 16 pathologically confirmed cases over 25 years. Cancer. 2003;98:356-62.

189. Shen Y, Ruan M, Luo Q, Yu Y, Lu H, Zhu R, et al. Brain metastasis from follicular thyroid carcinoma: treatment with sorafenib. Thyroid. 2012;22:856-6

190. Tala H, Robbins R, Fagin JA, Larson SM, Tuttle RM. Five-year survival is similar in thyroid cancer patients with distant metastases prepared for radioactive iodine therapy with either thyroid hormone withdrawal or recombinant human TSH. J Clin Endocrinol Metab. 2011;96:2105-11.

191. Klubo-Gwiezdzinska J, Burman KD, Van Nostrand D, Mete M, Jonklaas J, Wartofsky L. Radioiodine treatment of metastatic thyroid cancer: relative efficacy and side effect profile of preparation by thyroid hormone withdrawal versus recombinant human thyrotropin. Thyroid. 2012;22:310-7. 